MAGNITUDE AND FREQUENCY OF FLOODS IN RURAL AND

URBAN BASINS OF NORTH CAROLINA

By H. Curtis Gunter, Robert R. Mason, and Timothy C. Stamey

U.S. GEOLOGICAL SURVEY

Water-Resources Investigations Report 87-4096

Prepared in cooperation with the

THE NORTH CAROLINA DEPARTMENT OF TRANSPORTATION, THE NORTH CAROLINA DEPARTMENT OF NATURAL RESOURCES

AND COMMUNITY DEVELOPMENT,

AND OTHER STATE AND FEDERAL AGENCIES

Raleigh, North Carolina

1987 
DEPARTMENT OF THE INTERIOR

DONALD PAUL HODEL, Secretary

U.S. GEOLOGICAL SURVEY

Dallas L. Peck, Director

For additional information write to:

District Chief U.S. Geological Survey Post Office Box 2857 Raleigh, North Carolina 27602
Copies of this report can be purchased from:

U.S. Geological Survey Books and Open-File Reports Box 25425, Federal Center Denver, Colorado 80225 


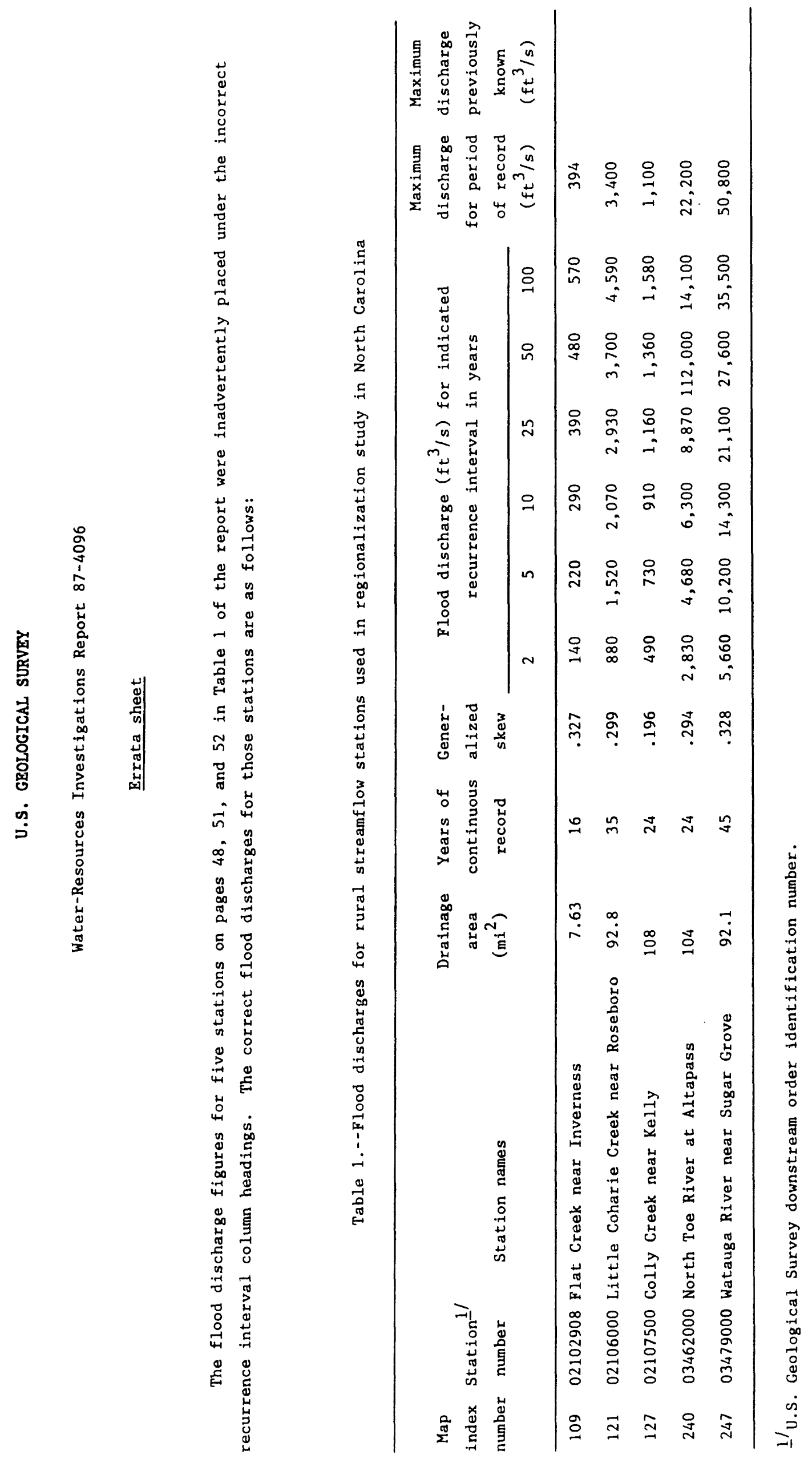




\section{CONTENTS}

Page

Abstract . . . . . . . . . . . . . . . . . . . 1

Introduction . . . . . . . . . . . . . . . . . . . . . 2

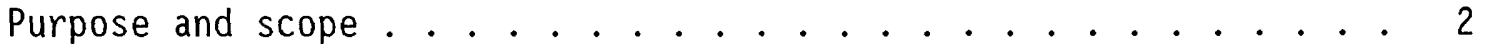

Description of the area.................. . . 3

Topography and drainage. . . . . . . . . . . . . 6

Precipitation. . . . . . . . . . . . . . . . 8

Historical floods. . . . . . . . . . . . . . . 8

Previous investigations . . . . . . . . . . . . . . . 9

Acknowledgments .. . . . . . . . . . . . . . . . 10

Magnitude and frequency of floods in rural basins. . . . . . . . . . . . 10

Log-Pearson Type III analysis . . . . . . . . . . . . . . 11

Coefficient of skewness . . . . . . . . . . . . . . 12

Regression model....................... 13

Basin characteristics... . . . . . . . . . . . . . 14

Regression analysis.................... . . 15

Accuracy of the regional relations. . . . . . . . . . . . 16

Determination of flood magnitude and frequency. . . . . . . . . 18

Gaged sites. . . . . . . . . . . . . . . . . 18

Ungaged sites. . . . . . . . . . . . . . . . . 19

Examples....................... 20

Magnitude and frequency of floods in urban basins. . . . . . . . . . 25

Coastal Plain.................... . . . 25

Piedmont. . . . . . . . . . . . . . . . . . 32

Summary. . . . . . . . . . . . . . . . . . . . . . . 35

Selected references. . . . . . . . . . . . . . . . . 38

Glossary . . . . . . . . . . . . . . . . . . . . 41

\section{ILLUSTRATIONS}

Page

Figures 1-2. Maps showing:

1. Location of rural streamflow stations used in regionalization study in western North Carolina. . 4

2. Location of rural streamflow stations used in regionalization study in eastern North Carolina. . 5 
Figures 3-5. Graphs showing:

3. Variation of flood discharge with drainage area in the Blue Ridge-Piedmont hydrologic area for selected recurrence intervals . . . . . . . 21

4. Variation of flood discharge with drainage area in the Coastal Plain hydrologic area for selected recurrence intervals . . . . . . . . 22

5. Variation of flood discharge with drainage area in the Sand Hills hydrologic area for selected recurrence intervals. . . . . . . . . 23

6. Map showing location of urban basin streamflow stations in the Piedmont and Coastal Plain provinces . . . . . . . . 27

\section{TABLES}

Table 1. Flood discharges for rural streamflow stations used in regionalization study in North Carolina. . . . . . . . 45

2. Regional flood relations for rural basins. . . . . . . . . 17

3. Accuracy of prediction of the regional flood relations for rural streams. . . . . . . . . . . . . . 17

4. Some basin and climatic characteristics for selected urban basins in the Coastal Plain province ........ . 26

5. Model calibration statistics for Coastal Plain urban basins. . 28

6. Summary of 10- and 100-year peak discharges in urban basins from simulated data and nationwide relations for the Coastal Plain province............ . . 31

7. Average standard error of prediction of nationwide relations in the Coastal Plain province. . . . . . . 32

8. Some basin and climatic characteristics for selected urban basins in the Piedmont province. . . . . . . . . 33

9. Summary of 25- and 100-year peak discharges in urban basins from simulated data (Putnam, 1972) and nationwide relations for the Piedmont province. . . . . . . . 34

10. Average standard error of prediction of nationwide relations in the Piedmont province ......... 35 


\section{ABBREVIATIONS AND CONVERSION FACTORS}

The following factors may be used to convert inch-pound units published herein to metric units.
Multiply inch-pound unit
By
To obtain metric unit

\section{Length}

inch (in.)

foot $(\mathrm{ft})$

mile $(\mathrm{mi})$
25.4

0.3048

1.609 millimeter $(\mathrm{mm})$

meter $(m)$

kilometer $(\mathrm{km})$

\section{Gradient}

foot per mile $(\mathrm{ft} / \mathrm{mi})$

0.1894

meter per kilometer $(\mathrm{m} / \mathrm{km})$

\section{Area}

square mile $\left(\mathrm{mi}^{2}\right)$

2.590

square kilometer $\left(\mathrm{km}^{2}\right)$

\section{Flow}

cubic foot per second $\left(\mathrm{ft}^{3} / \mathrm{s}\right)$

0.02832 cubic meter per second $\left(\mathrm{m}^{3} / \mathrm{s}\right)$

\section{Velocity}

feet per second $(\mathrm{ft} / \mathrm{s})$

0.3048

meter per second $(\mathrm{m} / \mathrm{s})$

inche per hour ( $\mathrm{in} / \mathrm{hr}$ )

25.4

millimeter per hour $(\mathrm{mm} / \mathrm{hr})$

Sea level: In this report "sea level" refers to the National Geodetic Vertical Datum of 1929 (NGVD of 1929)--a geodetic datum derived from a general adjustment of the first-order level nets of both the United States and Canada, formerly called "Mean Sea Level of 1929." 


\section{SYMBOLS}

Notation

Explanation

A. . . . . . . Drainage area, in square miles

$A_{g} \cdot . \cdot . \cdot . \cdot . \cdot$. Gaged drainage area, in square miles

$A_{u} \cdot . \cdot . \cdot . \cdot . \cdot$. Ungaged drainage area, in square miles

$\Delta A$. . . . . . . . Difference in drainage area

b. ......... . Drainage area exponent

BDF. . . . . . . Basin development factor

EY . . . . . . . . Equivalent years of record

G. . . . . . . . Station skew coefficient

$\bar{G}$. . . . . . . . . Generalized skew coefficient

$G_{W}$......... . Weighted skew coefficient

IA . . . . . . . Impervious area, in percent of drainage basin

$\mathrm{K}_{\mathrm{T}} \cdot . \cdot . \cdot . \cdot$. Scale factor

L. ........ . Basin length, in miles, along main channel

M. . . . . . . . . . Logrithmic mean

$\mathrm{MSE}_{\bar{G}} \cdot$. . . . . . Mean-square error of generalized skew coefficient

$\mathrm{MSE}_{\mathrm{G}}$. . . . . . . . Mean-square error of station skew coefficient

N. . . . . . . . Number of years of record

P. . . . . . . . Mean annual precipitation, in inches

$\mathrm{Q}_{\mathrm{g}}$.......... Station discharge, in cubic feet per second

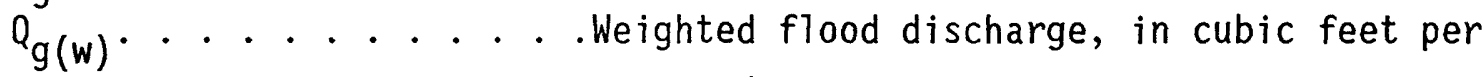
second

$Q_{n}$............ Regional flood discharge, in cubic feet per second

$\mathrm{Q}_{\mathrm{T}}$............. Estimate of flood discharge of a given recurrence interval, $T$, in cubic feet per second

$Q_{u}$. . . . . . . Ungaged flood discharge, in cubic feet per second

$Q_{u(w)} \cdot . \cdot . . . .$. . Ungaged weighted flood discharge, in cubic feet per second

$\mathrm{RI}_{2} \cdot$. . . . . . . Rainfall intensity, 24-hour duration, 2-year recurrence interval, in inches 
SYMBOLS, Continued

Notation

\author{
Explanation
}

RMS. . . . . . . Root mean squared, in percent

$\mathrm{RQ}_{\mathrm{T}}$.................. Rural peak flood discharge, in cubic feet per second, of given recurrence interval, $T$

S.......... Standard deviation

SI . . . . . . Soil infiltration index, in inches per hour

SL . . . . . . . Channel slope, in feet per mile

ST . . . . . . . . Storage

UQ .......... Urban peak flood discharge, in cubic feet per second

$\bar{x}$. . . . . . . . . . . Mean 


\title{
MAGNITUDE AND FREQUENCY OF FLOODS IN RURAL AND \\ URBAN BASINS OF NORTH CAROLINA
}

\author{
by \\ H. Curtis Gunter, Robert R. Mason, and Timothy C. Stamey
}

\section{ABSTRACT}

This report presents regional relations for estimating the magnitude and frequency of flood discharges of rural basins throughout North Carolina. Applicability of the nationwide urban flood relations in the Piedmont and Coastal Plain provinces is evaluated.

Data for 254 gaging stations on rura 1 streams with 10 or more years of record were used in multiple linear-regression analyses with basin and climatic variables to derive regional relations for estimating flood discharges having recurrence intervals of 2- to 100 -years. Rural relations are presented for three hydrologic areas: (1) Blue Ridge-Piedmont, (2) Coastal Plain, and (3) Sand Hills. Drainage area is the only basin characteristic in the relations. The average standard error of estimate of the relations for the Blue Ridge-Piedmont, Coastal Plain, and Sand Hills hydrologic areas is 44,39 , and 24 percent, respectively. Flood discharges for the 2-, 5-, 10-, 25-, 50-, and 100-year recurrence intervals for the 254 streamflow stations used in the regionalization study are also presented.

Flood-frequency distributions of simulated annual maximum discharges for four urban basins in the Coastal Plain indicate that the nationwide relations are applicable in that province. The root mean squared error for the 10 - and 100-year flood discharges, using the nationwide relations, is 44 and 49 percent, respectively.

Simulated data for six sites in the Piedmont were used to analyze the applicability of the nationwide urban relations in that province. The root mean squared error is 64 percent for the 10-year flood and 42 percent for the 100-year flood. No recommendation is made concerning use of the nationwide relations in the Piedmont. 


\section{INTRODUCTION}

Information on the magnitude and frequency of floods serves both economic and engineering needs in developments along streams and rivers. The information is an important criterion in bridge and culvert design, serves as a basis for flood plain regulation and establishment of equitable flood-insurance rates, and is useful in the design of flood control and drainage structures.

The U.S. Geological Survey, in cooperation with a number of State and local agencies, has conducted several studies to develop or improve procedures for estimating peak discharges on North Carolina streams that have predominately rural basins. Urbanization of a watershed can produce substantial changes in flood-runoff characteristics; therefore, regional relations for rural basins are not applicable to urban streams. Some method to account for, or estimate, the effects of urbanization is necessary. Putnam (1972) presented relations to estimate urban peak discharges in the Piedmont province. These equations were not recommended for use in other physiographic provinces of North Carolina because no data were available from those areas to test the applicability of the equations.

In 1976, the U.S. Geological Survey, in cooperation with the North Carolina Department of Transportation, began a study to determine urban flood relations for the Coastal Plain. The study was expanded in 1984 to test the applicability of nationwide flood relations (Sauer and others, 1983). The nationwide relations require an estimate of the rural flood discharges as input. Therefore, the study was further expanded to update regional flood relations for rural North Carolina streams (Jackson, 1976).

\section{Purpose and Scope}

The purpose of this report is to present and illustrate methods to estimate the magnitude and frequency of floods of rural streams throughout North Carolina and to verify flood relations for urban streams in the Piedmont and Coastal Plain. Data are not available to evaluate the applicability of flood relations for urban streams in the Blue Ridge province. 
This report is divided into two major parts. The first part presents updated regional peak discharge relations for rural streams. Annual maximum discharges at 254 rural stream stations with 10 or more years of record were used in the study. Resulting regional relations are applicable to streams that have little or no discharge data. Restrictions on the application and use of the relations are discussed. The second part of this report verifies applicability of nationwide relations in urban areas of the Coastal Plain and in the Piedmont. Simulated annual maximum discharges for four urban basins in the Coastal Plain were available for testing the nationwide relations. Similar data were available for six urban basins in the Piedmont for testing nationwide relations. The results of the tests are also discussed.

\section{Description of the Area}

North Carolina occupies parts of the South Atlantic-Gulf, Tennessee, and Ohio Water-Resources Regions. About 87 percent of the State's 1 and surface is located in the South Atlantic-Gulf Region. The 52,712 squaremile $\left(\mathrm{mi}^{2}\right)$ area of the State includes three major physiographic provinces: (1) Blue Ridge, (2) Piedmont, and (3) Coastal Plain (fig. 1) as defined by Fenneman (1938). A subdivision of the Coastal Plain known as the Sand Hills, described by Stuckey (1965), is also recognized. The Sand Hills lie along the southern border of the State in the southwestern part of the Coastal Plain province and, for purposes of this report, are defined to include the area mapped as the Sand Hills soils system by Daniels and others (1984) plus an area extending just east of the Lumber River (fig. 2).

Flood discharges and flood peaks are related to the differences in the characteristics of topography, drainage basin geometry and soils among the physiographic provinces and the Sand Hills. Analysis of those characteristics in each of these areas shows that the combined provinces of the Blue Ridge and Piedmont, the Coastal Plain province (excluding the Sand Hills), and the Sand Hills may be considered as separate regional hydrologic areas. For the purpose of describing the magnitude and frequency of floods in rural areas across the State, the designation of these three regions as hydrologic areas is useful (figs. 1 and 2). 


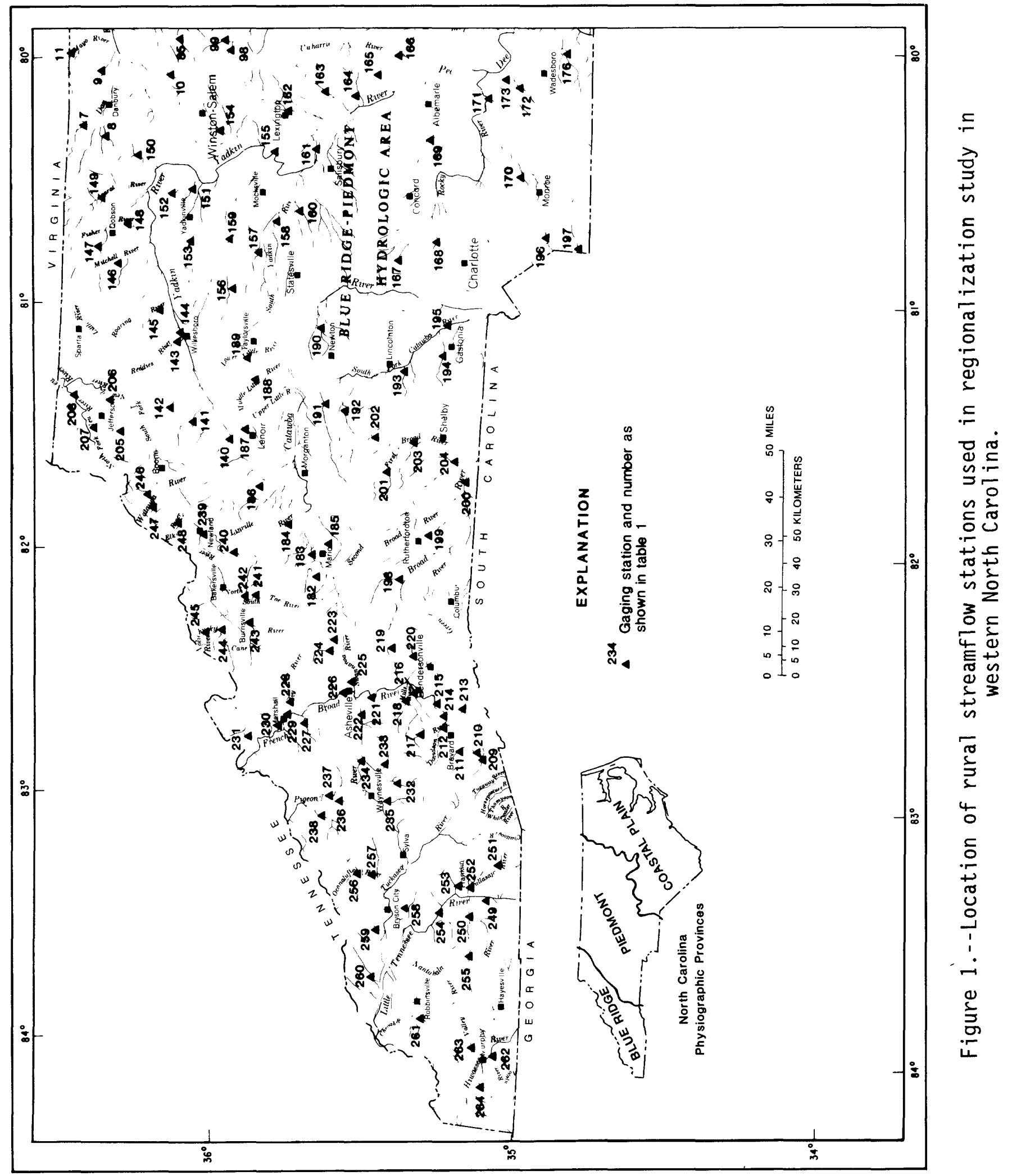




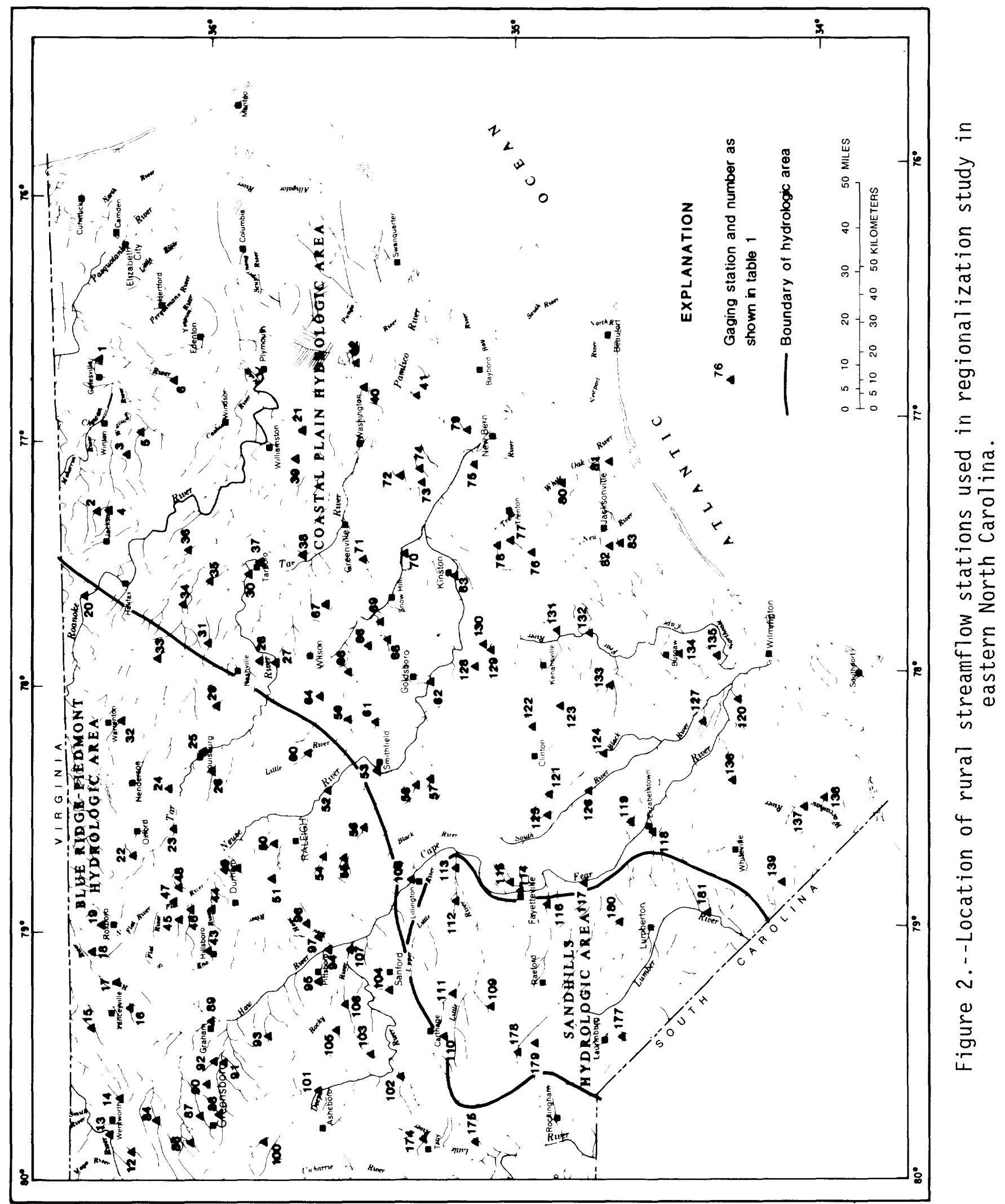




\section{Topography and Drainage}

The North Carolina portion of the Blue Ridge province is bordered on the north and west by the States of Virginia and Tennessee; on the south by Georgia and South Carolina; and on the east by the Piedmont province (fig. 1). The eastern boundary of the Blue Ridge province is an abrupt scarp rising some 1,500 to 2,500 feet above the Piedmont. Rough mountainous terrain, rock outcrops, and clayey soils are characteristic of the province. Elevations range from 6,684 feet above sea level at Mount Mitche11, the highest peak in the United States east of the Mississippi River, to 3,000 feet above NGVD of 1929 along the eastern boundary of the province (Stuckey, 1965). River basins are narrow; tributaries are short and tend to be oriented perpendicular to receiving streams. Typical stream slopes are 30 to 100 feet per mile $(\mathrm{ft} / \mathrm{mi})$, but some slopes are as small as $4 \mathrm{ft} / \mathrm{mi}$ in basins greater than $500 \mathrm{mi}^{2}$, and some are as 1 arge as $650 \mathrm{ft} / \mathrm{mi}$ in headwaters. Many mountain streams flow at velocities exceeding 10 feet per second ( $\mathrm{ft} / \mathrm{sec}$ ) during floods. Even on the larger streams, floods hydrographs are sharp and pass quickly, usually within 24 hours.

The Piedmont province of North Carolina lies between the Blue Ridge and Coastal Plain provinces and is bounded by Virginia on the north and South Carolina to the south. The province is characterized by rolling to steep hills and ridges which trend northeast to southwest (Stuckey, 1965). Elevations in the Piedmont range from over 1,500 feet above sea level at many points along the western boundary to 300 feet above sea level along the eastern boundary. The soils are derived from the weathered rock beneath and are usually clayey or silty loams. Drainage patterns are mostly dendritic rectilinear. Stream slopes average about $20 \mathrm{ft} / \mathrm{mi}$, ranging from 10 to several hundred feet per mile. Streamflow velocities of 5 to $10 \mathrm{ft} / \mathrm{sec}$ occasionally occur during floods. Depending on the size of the basin and intensity of the storm, flood waters may require a few hours to a few days to peak and pass the basin outlet.

The Coastal Plain is the easternmost province of North Carolina, bounded on the west by the Piedmont and by the Atlantic Ocean on the east. The Virginia and South Carolina State lines delineate the north and south extent of this province in North Carolina. Excluding the Sand Hills 
hydrologic area, elevations range from 400 feet above sea level in the southwestern Coastal Plain to sea level at the Atlantic coast. The Coastal Plain is characterized by moderate to gentle land and stream slopes in the west to very flat slopes in the east. Typical surface slopes range from 10 to $20 \mathrm{ft} / \mathrm{mi}$, and stream slopes rarely exceed $10 \mathrm{ft} / \mathrm{mi}$. Soils are derived from marine sand and clay deposits; the sandy soils have a tendency to absorb much water.

Coastal Plain streams generally are braided near the coast, with many anabranches and distributaries meandering through swamps. Here, drainage divides are poorly defined or nonexistent. To increase drainage of lowlying lands, extensive networks of canals and cross-ditches have been constructed, which may alter runoff characteristics of entire basins. Many stream channels have been cleared of blockages or channelized. Vast areas along stream courses are susceptible to flooding. Streams that may be a few tens of feet wide during dry weather often inundate areas several thousand feet wide during floods of minor magnitude. Floods are attenuated and peaks build slowly; flood peaks on major Coastal Plain streams may not occur for a week or longer following the flood-producing rains.

The Sand Hills hydrologic area is part of the Coastal Plain province along the South Carolina border (fig. 2). The topography is characterized by broad and rolling uplands with highly directed, steep-sided valleys. Elevations range from about 500 to 700 feet above sea level. The soils are typically light-colored, loose, fine to coarse sandy loam that Daniels and others (1984, p. 14) describe as a "billowing, nearly white sea of sand." Drainage is dendritic with typical stream slopes of $20 \mathrm{ft} / \mathrm{mi}$.

Hydrologically, the Sand Hills are unique in North Carolina; storm runoff is considerably less here than that associated with the other hydrologic areas because of the absorbent nature of the sandy soils. Consequently, streams respond slowly to all but the most extreme rainfa11, and flood peaks are broad crested. 


\section{Precipitation}

In North Carolina, most precipitation occurs as rain and is distributed fairly uniformly throughout the year, but areal variations are extreme. The highest annual precipitation found in the eastern United States, 82 inches, occurs in the State's B]ue Ridge province as does the State's lowest precipitation of 40 inches only $50 \mathrm{mi}$ (miles) away (Eder and others, 1983). This extreme difference is caused by the orographic effect of the mountains on precipitation in western North Carolina.

Eastward, across the Piedmont, annual precipitation decreases gradually reaching a low of approximately 43 inches near the central section of the province then gradually increases over the Coastal Plain to approximately 54 inches near the Atlantic Coast. Storm rainfall maps generally indicate similar patterns with rainfall intensity highest in the extreme southern portion of the Blue Ridge and along the Atlantic Ocean and lowest over the central section of the Piedmont (U.S. Weather Bureau, 1961).

Most floods in North Carolina result from either thunderstorms or tropical storms. Thunderstorms are mostly associated with the warm season but may occur any time during the year; they are frequently intense and generally affect small areas. More thunderstorms occur in the Blue Ridge than in any other area of the State, and the northeastern portion of the Coastal Plain receives the least number (Kopec and Clay, 1975).

Tropical storms and hurricanes are most frequent during late summer and fa11. They can cover tens of thousands of square miles, last for days, and deliver enormous quantities of rain. Major floods, especially those on larger streams, are usually associated with these storms. It should be emphasized, however, that the State has no flood season and that major floods might occur during any season of the year.

\section{Historical Floods}

Since 1900, major floods have occurred in 1916, 1928, 1940, 1945, 1955, and 1977, but statewide flooding caused by a single storm or storm system is 
a rarity. For instance, the 1955 flood occurred in eastern North Carolina and the floods of 1977 were limited to portions of western North Carolina. of the preceding major floods, the one causing the most damage was that of August 1940 which also was the most widespread. Quite often, however, record floods on smaller headwater streams have resulted from locally intense rains which subsequently had little effect on the larger main stem. Because of the variability of rainfall during and between storms, differences in soil characteristics among basins, varying antecedent soilmoisture conditions, and a host of other variables, the same storm may produce a record flood in one basin and only moderate flooding in an adjacent basin. For these and other reasons, dates of occurrence of maximum floods are quite variable across the State and even within the same river basin.

\section{Previous Investigations}

Three previous reports by Speer and Gamble (1964a, 1964b, 1965), each covering a portion of North Carolina, have presented methods for estimating flood magnitudes for various recurrence intervals. However, the methods are applicable only to rural basins more than about $150 \mathrm{mi}^{2}$ in size. Beginning in 1952, 120 crest-stage stations were established in rural basins generally less than $50 \mathrm{mi}^{2}$ in size. Records for these and other gaging stations through 1963 were used by Hinson (1965) to develop statewide flood relations for rural basins less than $150 \mathrm{mi}^{2}$ in size. Jackson (1976), using 10 additional years of record, better defined statewide flood relations, especially for basins less than $50 \mathrm{mi}^{2}$ in size. Generally, results of previous studies were applicable to rural basins in North Carolina with the exception of streams subject to regulation, tide effect, urbanization, channel improvement, and those streams with basins covering less than 0.5 $\mathrm{mi}^{2}$.

Nationwide, numerous reports are available which describe the effects of urban development on floods; however, relatively few include predictive techniques which are applicable to North Carolina streams. Putnam (1972) determined that urban development in the State's Piedmont province significantly affected flood flows and presented relations including indices 
of lag time and impervious cover to account for the increase in peak discharge caused by urbanization. Sauer and others (1983) developed relations for nationwide application. Their technique uses the flood magnitude for rural streams as a base; parameters reflective of the degree of urban development are used to adjust the flood magnitude from rural to urban conditions. This report presents an analysis of the applicability of these nationwide relations to the Coastal Plain and Piedmont provinces of North Carolina.

\section{Acknowledgments}

The authors thank the many persons who have given time, information, and guidance during this study. Particular thanks are given to personnel of the National Climatic Data Center, U.S. Department of Commerce, Asheville, North Carolina, and to Roy H. Bingham, Hydrologist, and other persons in the Geological Survey who assisted in the data collection and in the preparation of this report.

This report, which supercedes all previous U.S. Geological Survey flood-frequency reports for North Carolina, is the result of a cooperative agreement between the North Carolina Department of Transportation and the U.S. Geological Survey. Most of the flood records used in this study were collected in cooperation with the North Carolina Department of Natural Resources and Community Development, the U.S. Army Corps of Engineers, the Tennessee Valley Authority, and other State and local governmental agencies.

\section{MAGNITUDE AND FREQUENCY OF FLOODS IN RURAL BASINS}

Streamflow data for 254 predominately rural streamflow stations having records of at least ten annual maximum discharges not significantly affected by tides, regulation, diversion, or channelization were used in this study (figs. 1 and 2). Of these stations, 177 were in the Blue Ridge-Piedmont hydrologic area, 69 were in the Coastal Plain hydrologic area, and eight were in the Sand Hills hydrologic area. Drainage areas of the stations in the Blue Ridge hydrologic area range in size from 0.25 to $8,384 \mathrm{mi}^{2}$, in the 
Coastal Plain hydrologic area from 0.63 to $2,692 \mathrm{mi}^{2}$, and in the Sand Hills hydrologic area from 7.57 to $1,228 \mathrm{mi}^{2}$.

The relation of annual maximum discharges to their probability of exceedence, or recurrence interval, is referred to as a flood-frequency distribution. Recurrence interval is the average interval of time within which the given flood will be exceeded once. Flood-frequency distributions (table 1) were determined for each station using U.S. Geological Survey guidelines and procedures outlined by the Water Resources Council. The "Guidelines for Determining Flood Flow Frequency," Bulletin 17B of the U.S. Water Resources Council (1981), is a major extension of the work previously completed by the Council to promote a consistent approach to flood frequency determination. Suggested procedures are provided in Bulletin 17B for defining flood-frequency distributions for streamflow stations. These procedures form the basis for the station data analysis methods incorporated in this report. A brief summary of the procedures used is outlined below:

1. A Pearson Type III distribution was fitted to logarithms of observed annual maximum discharges for each station;

2. The generalized skew and station skew coefficients were weighted to form an estimate of skew for each basin; and

3. Frequency distributions were adjusted for outliers and historic peaks.

\section{Log-Pearson Type III Analysis}

The Pearson Type III distribution with base 10 logarithmic transformation of annual maximum discharges was used to define station flood-frequency distributions. For this distribution, the peak discharge at selected T-year (2-,5-, 10-, 25-, 50-, and 100-year) recurrence intervals can be computed using the following equation:

$$
\log Q_{T}=M+K_{T} S
$$


where: $\quad Q_{T}=$ Estimate of the T-year flood from log-Pearson Type III distribution, in cubic feet per second;

$$
\begin{aligned}
M= & \text { Mean of the logarithms of the annual maximum discharges; } \\
\mathrm{K}_{\mathrm{T}}= & \text { A scale factor that is a function of the skew coefficient } \\
& \text { and recurrence interval; and } \\
\mathrm{S}= & \text { Standard deviation of the logarithms of the annual } \\
& \text { maximum discharges. }
\end{aligned}
$$

U.S. Geological Survey computer program J407, described by Kirby (1979), was used to fit the log-Pearson Type III distribution to annual maximum discharges for each station. Program 3407 includes many of the features described in Bulletin 17B (U.S. Water Resources Council, 1981) but requires the user to use judgement when providing data on historic peaks, specifying screening levels for outliers, and interpreting the frequency distribution.

\section{Coefficient of Skewness}

As defined in the previous section, the scale factor $\left(K_{T}\right)$ of the logPearson Type III analysis is a function of the recurrence interval and the skew coefficient. The accuracy of the station skew coefficient, as an estimate of the true skew of the frequency distribution, is generally a function of the length of record. The station skew is a measure of the past history of annual floods, and may be extremely unreliable when computed from short periods (less than 10 years) of record. The generalized skew coefficient is the average of the station skew coeficients in a given area having at least 25 years of record. The generalized skew coefficient can be averaged with the individual station skew coefficients to dampen the effects of extreme floods. Bulletin 17B (U.S. Water Resources Council, 1981) recommends that the station and the generalized skew coefficients be weighted inversely to their respective mean-square errors as follows: 


$$
G_{W}=\frac{M S E_{\bar{G}}(G)+M S E_{G}(\bar{G})}{M S E_{\bar{G}}+M S E_{G}}
$$

where: $\quad G_{W}=$ Weighted skew coefficient;

$$
\begin{aligned}
\operatorname{MSE}_{\bar{G}} & =\text { Mean-square error of generalized skew coefficient; } \\
G & =\text { Station skew coefficient; } \\
M_{\mathcal{G}} & =\text { Mean-square error of station skew coefficient; and } \\
\bar{G} & =\text { Generalized skew coefficient. }
\end{aligned}
$$

Flood discharges determined from the estimated flood-frequency distribution that were used in the regression analysis are listed in table 1 at the end of this report with exception of the deletions listed below. Locations of the streamflow stations are shown in figures 1 and 2 .

Station map index number

$53,110,111,114,117,179$

134

141,216

155

\section{Reason for deletion}

Basin in two hydrologic areas Indeterminate drainage area Short term flood record with one high annual flood discharge (high outlier) Regulated discharge

\section{Regression Model}

Regional flood relations were developed in this study by using multiple linear-regression analysis to relate flood discharges of selected recurrence intervals to selected basin and climatic characteristics. Resulting regional flood relations are statistical expressions of flood discharge as a function of significant basin and climatic characteristics; indices of accuracy and reliability are also provided. 
Flood discharges (dependent variables) were related to the basin and climatic factors (independent variables) by step-backward and step-forward multiple-regression analysis. In step-backward multiple regression, a set of equations is developed relating the dependent variable to all independent variables then proceeding step-wise where, at each step, the least significant independent variable, as indicated by the Student's t-test, is deleted from the equation. Step-forward multiple-regression differs in that at each step a11 variables are tested, and the one making the greatest reduction in standard error is added to the equation. This procedure continues, retaining the next most significant variable at each step, until all variables that are significant are retained in the equation. Results were the same for both methods.

The hydrologic model sought has the form:

$$
Q_{T}=B_{0} x_{1}^{B_{1}} x_{2} B_{2} \quad x_{3}^{B_{3}} \ldots
$$

where $Q_{T}$ represents the $T$-year flood discharge or dependent regression variable;

$B_{0}, B_{1}, B_{2}, B_{3}$ are regression coefficients; and

$X_{1}, X_{2}, X_{3}$ are the basin characteristics or independent variables. The hydrologic model has a linear form as follows:

$$
\log Q_{T}=\log B_{0}+B_{1} \log X_{1}+B_{2} \log X_{2}+B_{3} \log x_{3}+\ldots
$$

This logarithmic relation is the form that was used in this study.

\section{Basin Characteristics}

The basin characteristics used in the regionalization study are described below. The variables were chosen because they are most likely to influence flood discharge. Not all variables tested were statistically significant. Consequently, insignificant characteristics do not appear in the final regional relations. A11 basin characteristics with zero values were changed to 1 percent so that logarithmic transformations could be made. 
1. Drainage area, $A$, in square miles, as determined from the best available topographic map.

2. Channel slope, SL, in feet per mile, is the average slope between points located at 10 and 85 percent of the main channel length upstream from the gage to the basin divide.

3. Length of the main channel, $L$, in miles, is the distance along the length of the main stream channel upstream from the gage to the basin divide.

4. Storage, ST, in percent, is the percentage of the drainage area that is covered by lakes, ponds, swamps, etc.

5. Soil-infiltration index, SI, in inches per hour is an index to soil infiltration capacity. The indices were determined from soil samples collected, analyzed, and reported by Lutz (1969), and generalized on the basis of a map showing soil types prepared by Lee (1955).

6. Precipitation, mean annual, $P$, in inches, was determined directly from maps published by Carney (1960) for basins generally east of and lower than the 1,000-ft elevation contour line along the eastern slopes of the Appalachian divide. For stations west of that contour 1 ine, mean annual precipitation was computed from a curve relating precipitation to mean basin elevation and orgraphic factors (Goddard and others, 1970).

7. Rainfall intensity, $\mathrm{RI}_{2}, 24$-hour duration, 2-year recurrence interval, in inches, was determined for each basin from Technical Paper No. 40, Rainfall Frequency Atlas of the United States, U.S. Weather Bureau (1961).

\section{Regression Analysis}

Regionalization studies by Goddard and others (1970) and by Jackson (1976) indicated that the relation of flood discharge to basin and climatic characteristics is variable across the State. However, for this study, statewide regressions were initially attempted using all seven basin and climatic characteristics; only drainage area, slope, and storage were significant at the 5 percent level. Standard errors of estimates ranged 
from 49 to 72 percent. The improvement resulting from including variables other than drainage area in the relations was not great, averaging only 9 percent. To evaluate spatial variation in the results, maps of the ratios of observed discharges to those computed from the regression equations for each station were prepared. These maps showed that the statewide regression equations gave discharges that were consistently high for stations in the Coastal Plain and low for stations in the Blue Ridge and Piedmont. Predicted discharges for the Sand Hills were particularly high. Accordingly, the State was divided into three hydrologic areas: the Blue Ridge-Piedmont, the Coastal Plain, and the Sand Hills as shown in figures 1 and 2. These hydrologic areas apply only to use of the rural relations.

Once the hydrologic areas were established, regressions were then recomputed for each area. Standard errors were reduced 10 to 20 percent. Drainage area was the most statistically significant variable; the use of the other variables in the equations did not reduce the standard error more than 2 percentage points for the Blue Ridge-Piedmont hydrologic area. In the Coastal Plain, the use of variables in addition to drainage areas reduced the standard error an average of 3 percentage points. In the Sand Hills, only drainage area was significant at the 5 percent level. Thus, drainage area was the only variable retained in the relations for the three hydrologic areas because the improvement in the prediction results does not justify the effort involved in including other variables. Regional flood relations for rural sites for the three hydrologic areas are summarized in table 2.

\section{Accuracy of the Regional Relations}

The accuracy of regional relations (table 2) may be expressed as the average standard error of estimate and the equivalent years of record. The average standard error of estimate is a measure of the difference between the peak flow from the station flood-frequency distribution (table 1) and estimates obtained from the regional flood relations (table 2). The average standard error of the regional relations is the range of error about the regression curve within which two-thirds of the estimates are expected to fall. The average standard error of estimate of the relations for the Blue 
Ridge-Piedmont, Coastal Plain, and Sand Hills hydrologic areas is 44, 39, and 26 percent, respectively.

Table 2.--Regional flood relations for rural basins

Flood discharge, $Q_{t}$

for recurrence

interva1 $T$ years
Hydrologic areas, A, drainage area in square miles

Sand Hills Coastal Plain Blue Ridge-Piedmont

$29.7 A^{0.733}$

$69.4 A^{0.632}$

$144 \mathrm{~A}^{0.691}$

$48.8 A^{0.738}$

$149 \quad A^{0.582}$

$248 \mathrm{~A}^{0.670}$

$64.4 A^{0.740}$

$225 \quad A^{0.559}$

$334 \mathrm{~A}^{0.665}$

$86.2 A^{0.751}$

$362 \quad A^{0.532}$

$467 \mathrm{~A}^{0.655}$

$105 \quad A^{0.757}$

$490 \quad A^{0.514}$

$581 \mathrm{~A}^{0.650}$

$126 \quad A^{0.763}$

$719 A^{0.643}$

The equivalent years of record (Hardison, 1971), is the number of years of streamflow record needed to provide an estimate equal in accuracy to that of the regional relation. The accuracy of the regional relations, average standard error of estimate, and equivalent years of record are summarized in table 3 .

Table 3.--Accuracy of prediction of the regional flood relations for rural streams

\begin{tabular}{|c|c|c|c|c|c|c|}
\hline \multirow[b]{2}{*}{$\begin{array}{c}\text { Recurrence } \\
\text { interval } \\
\text { in years }\end{array}$} & \multicolumn{2}{|c|}{ Sandhilis } & \multicolumn{2}{|c|}{ Coastal Plain } & \multicolumn{2}{|c|}{ Blue Ridge-Piedmont } \\
\hline & $\begin{array}{l}\text { Average } \\
\text { standard error } \\
\text { of estimate } \\
\text { in percent }\end{array}$ & $\begin{array}{l}\text { Equivalent } \\
\text { years of } \\
\text { record }\end{array}$ & $\begin{array}{l}\text { Average } \\
\text { standard error } \\
\text { of estimate } \\
\text { in percent }\end{array}$ & $\begin{array}{l}\text { Equivalent } \\
\text { years of } \\
\text { record }\end{array}$ & $\begin{array}{l}\text { Average } \\
\text { standard error } \\
\text { of estimate } \\
\text { in percent }\end{array}$ & $\begin{array}{l}\text { Equivalent } \\
\text { years of } \\
\text { record }\end{array}$ \\
\hline 2 & 18 & 7 & 34 & 4 & 38 & 2 \\
\hline 5 & 17 & 12 & 34 & 8 & 42 & 2 \\
\hline 10 & 19 & 14 & 35 & 10 & 40 & 4 \\
\hline 25 & 25 & 12 & 39 & 13 & 44 & 5 \\
\hline 50 & 29 & 14 & 43 & 16 & 48 & 7 \\
\hline 100 & 34 & 15 & 47 & 20 & 52 & 9 \\
\hline
\end{tabular}




\section{Determination of Flood Magnitude and Frequency}

Regional relations can be used to estimate flood discharges for ungaged sites and improve estimates for gaged sites. For gaged sites, the best estimate of the T-year flood is determined by weighting the regional and station estimates. The station estimate is from a log-Pearson Type III frequency distribution of the observed annual maximum discharges and the Water Resources Council (WRC) weighted skew coefficient. Accuracy, in equivalent years, for the weighted estimate is equivalent to the sum of the accuracy of each estimate, assuming the two estimates are independent.

For ungaged sites, the regional estimate can be improved if the site is located near a site on the same stream having at least 10 years of record. Accuracy of the weighted estimate depends on the relative proximity of the ungaged site to the gaged site. Sites with less than 10 years of record are treated as ungaged sites.

\section{Gaged Sites}

The best estimate of flood discharge for gaged sites can be determined from the following equation (Water Resources Counci1, 1981):

where:

$$
\log Q_{g(w)}=\frac{N \log Q_{g}+E Y \log Q_{n}}{N+E Y}
$$

\footnotetext{
$Q_{g(w)}=$ Weighted discharge for selected recurrence interval, in cubic feet per second;

$N=$ Number of years of record used to compute $Q_{g}$;

$Q_{g}=$ Station discharge for selected recurrence interval, in cubic feet per second;

$E Y=$ Equivalent years of record for $Q_{n}$ from table 3 ; and

$Q_{n}=$ Regional discharge for selected recurrence interval, in cubic feet per second.
} 
The accuracy of the weighted estimate, $Q_{g(w)}$, in equivalent years of record, is equal to $\mathrm{N}$ plus EY. Regional and station estimates tend to be independent when the area covered by the regionalization has a radius greater than 100 miles, and the periods of record of the data used in regionalization are long in comparison with that of the station for which the weighted estimate is sought (Water Resources Council, 1981). When estimates are not independent, accuracy is reduced in proportion to the degree of correlation of the estimates. The weighting techniques described in this report assume that regional and station estimates are independant.

Station flood discharges for selected recurrence intervals $(2,5,10$, 25, 50, and 100 years) are presented in table 1 for 264 stations, of which 254 were used for regression analysis. The flood values shown were computed using all available records through 1984 and, thus, supercede values published previously by Jackson (1976).

\section{Ungaged Sites}

Flood discharges for ungaged sites are determined by using the value of drainage area in the appropriate regional relation (table 2). Inspection of figures 1 and 2 is also required to determine the correct hydrologic area.

The regional estimate can be improved if the site is located on the same stream as a station with at least 10 years of record. This procedure should only be used to transfer flood discharges if the drainage area of the site is within 50 percent (either greater or less) of that at a gaging station on the same stream. Otherwise, the regional estimate at the ungaged site is the best estimate.

The adjusted estimate, $Q_{u}$, for an ungaged site can be determined as follows:

$$
Q_{u}=\left(\frac{A_{u}}{A_{g}}\right)^{b} Q_{g(w)}
$$


and a weighted value can be computed by the equation:

$$
Q_{u(w)}=\frac{2 \Delta A}{A_{g}} Q_{n}+\left(1-\frac{2 \Delta A}{A_{g}}\right) Q_{u}
$$

where: $\quad Q_{u}=$ Flood discharge at the ungaged site transferred from the gaging station by the drainage area ratio, in cubic feet per second;

$A_{u}=$ Drainage area of the ungaged site, in square miles;

$A_{g}=$ Drainage area of the gaging station, in square miles;

$\mathrm{b}=$ Drainage area exponent of the regional relation for the applicable hydrologic area and the selected recurrence interval;

$Q_{g(w)}=$ Weighted flood discharge from the gaging station, in cubic feet per second;

$q_{u(w)}=$ Weighted flood discharge at the ungaged site, in cubic feet per second;

$\Delta A=$ Difference in drainage areas of the gaging station and ungaged site, in square miles; and

$Q_{n}=$ Regional flood discharge at the ungaged site, in cubic feet per second.

\section{Examples}

Numerical and graphical examples are presented for determining the 100year flood discharges for an ungaged rural site. The numerical example requires the following steps:

(1) Determine that the site is not significantly affected by artificial regulation or urbanization, channel improvement, diversion, or tide;

(2) Determine the drainage area, $A$, in square miles, using the best available map (for example, 7.5 minute U. S. Geological Survey topographic maps);

(3) Determine the hydrologic areas (fig. 1 or 2) in which the drainage basin of the site is located; and

(4) Use appropriate equation (table 2) or graphs (figs. 3, 4, and 5). 


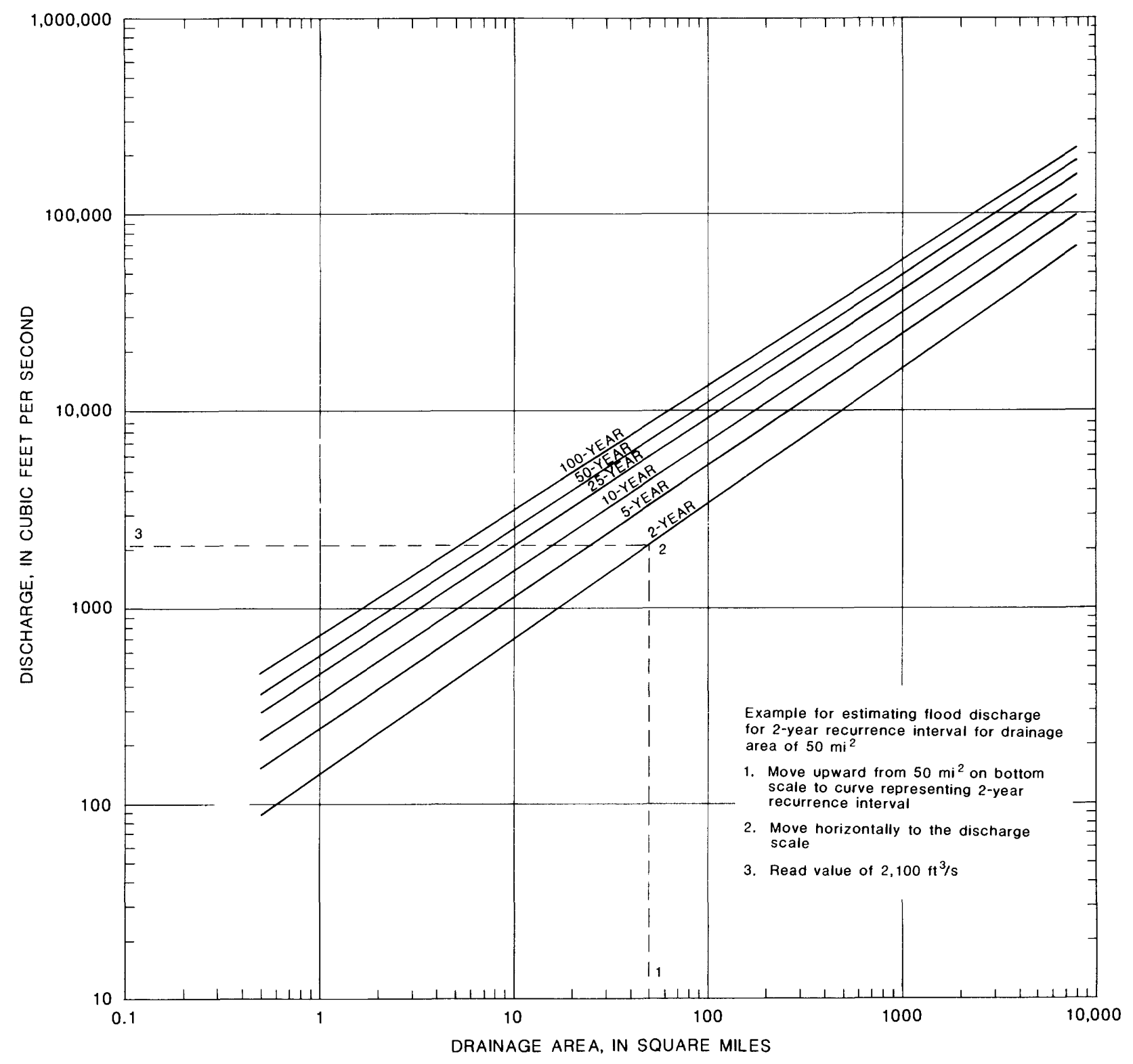

Figure 3.--Variation of flood discharge with drainage area in the Blue Ridge-Piedmont hydrologic area for selected recurrence intervals. 
Assume the selected site is in the Coastal Plain and has a drainage area of $50 \mathrm{mi}^{2}$ (from topographic map). Using regional relations for the Coastal Plain (table 2), computation of the flood discharge is as follows:

$$
\begin{aligned}
Q_{2} & =69.4 \mathrm{~A}^{0.632} \\
& =69.4(50)^{0.632} \\
& =820 \mathrm{ft}^{3} / \mathrm{s}
\end{aligned}
$$

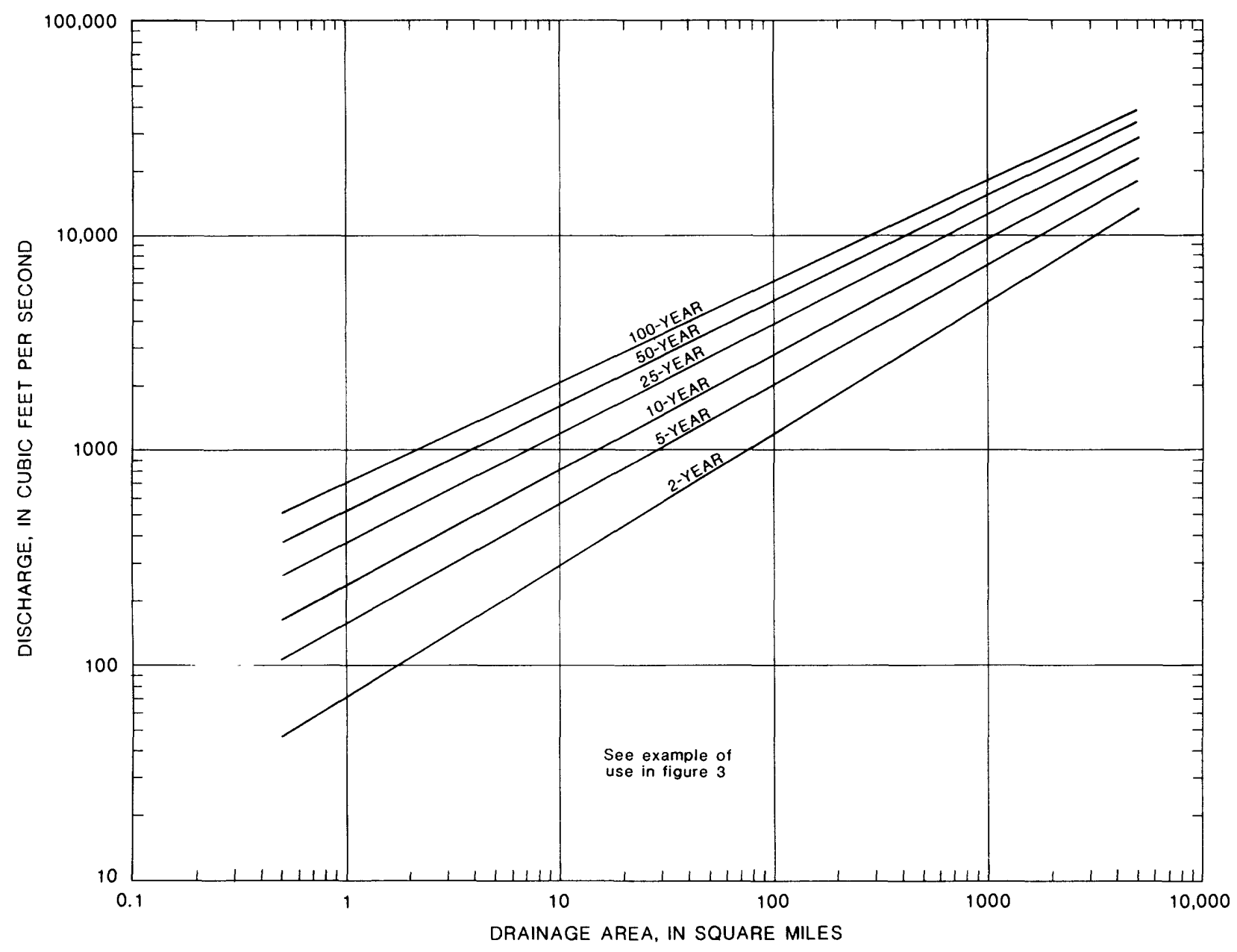

Figure 4.--Variation of flood discharge with drainage area in the Coastal Plain hydrologic area for selected recurrence intervals.

If the drainage basin lies in two hydrologic areas, discharge should be adjusted based on the proportion of the drainage area in each hydrologic area as illustrated in the following example. 


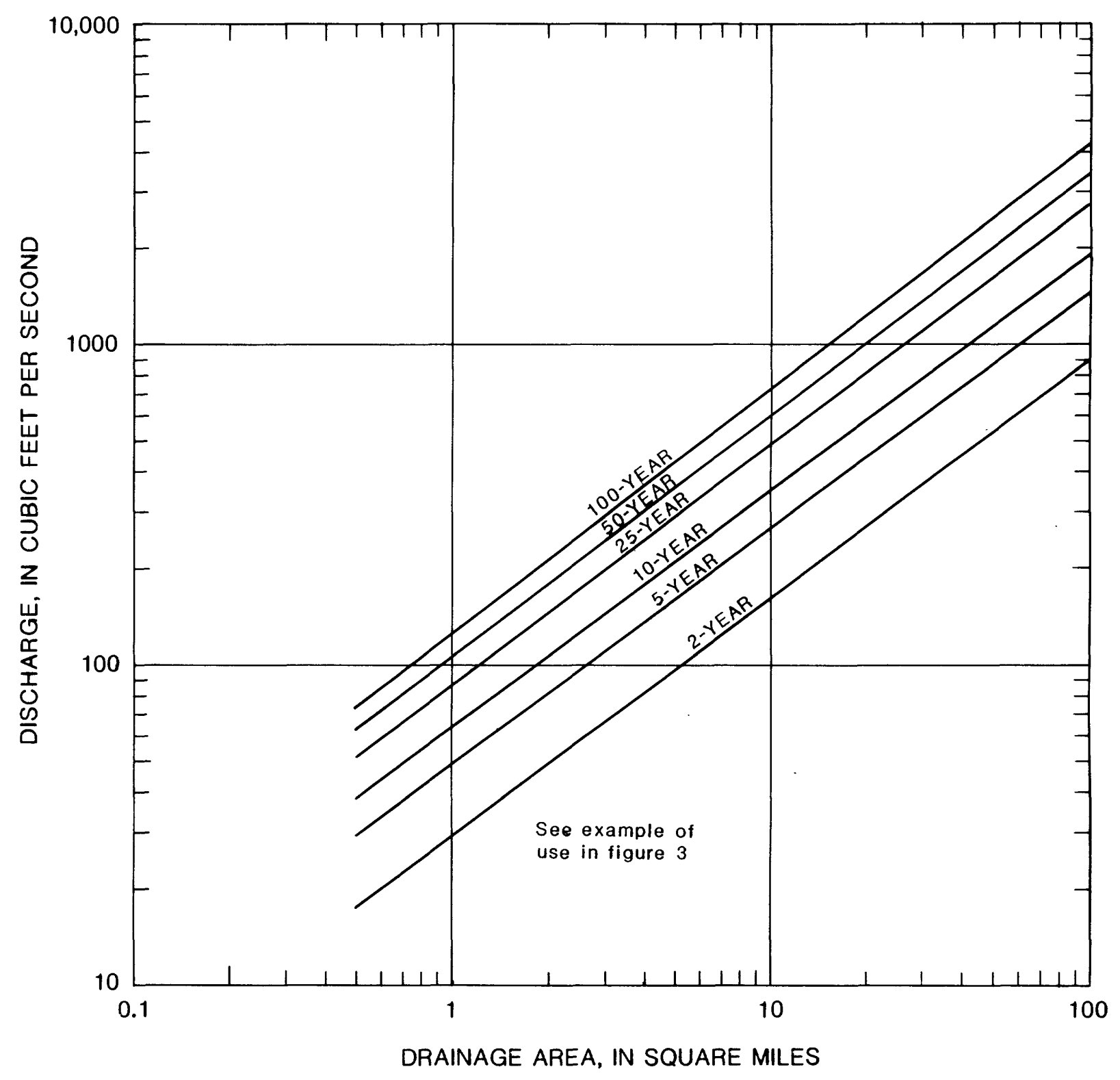

Figure 5.--Variation of flood discharge with drainage area in the Sand Hills hydrologic area for selected recurrence intervals.

Compute the 100-year flood discharge $\left(Q_{100}\right)$ for a gaged site (station 114, fig. 2 and table 1) on the Cape Fear River at Fayetteville, N.C., with a drainage area of $4,395 \mathrm{mi}^{2}$. This site drains $931 \mathrm{mi}^{2}$ of the coastal Plain hydrologic area and $3,464 \mathrm{mi}^{2}$ of the Blue Ridge-Piedmont hydrologic area. 
First compute $Q_{100}$ assuming that the drainage area is totally within the Blue Ridge-Piedmont and then compute $Q_{100}$ assuming that the drainage area is totally within the Coastal Plain:

Blue Ridge-Piedmont:

$$
\begin{aligned}
Q_{100} & =719 \mathrm{~A}^{0.643} \\
& =719(4395)^{0.643} \\
& =158,000 \mathrm{ft}^{3} / \mathrm{s}
\end{aligned}
$$

\section{Coastal Plain:}

$$
\begin{aligned}
Q_{100} & =653 \mathrm{~A}^{0.497} \\
& =653(4395)^{0.497} \\
& =42,200 \mathrm{ft}^{3} / \mathrm{s}
\end{aligned}
$$

Adjust $Q_{100}$ based on the percentage of the drainage area in each hydrologic area.

$$
\begin{aligned}
Q_{100} \text { (adjusted) } & =Q_{100} \text { BTue Ridge-Piedmont } \times \frac{3464}{4395}+Q_{100} \text { Coastal Plain } \times \frac{931}{495} \\
& =\left[158,000 \times \frac{3464}{4395}\right]+\left[42,200 \times \frac{931}{4395}\right] \\
& =125,000+8,940 \\
& =134,000 \mathrm{ft}^{3} / \mathrm{s} \text { (rounded) }
\end{aligned}
$$

The adjusted $Q_{100}$ for this site in which the drainage area is within more than one hydrologic area is $134,000 \mathrm{ft} 3 / \mathrm{s}$. This compares to a station discharge $\left(Q_{g}\right)$ of a 100-year flood of $122,000 \mathrm{ft}^{3} / \mathrm{s}$ for the site, or within the standard error of estimate of \pm 47 percent for the Coastal Plain hydrologic area (table 3 ).

The regional flood relations for rural streams in the Blue RidgePiedmont, Coastal Plain, and Sand Hills hydrologic areas (table 2) are shown in graphical form in figures 3,4 , and 5 , respectively. The following example is given to illustrate use of the curves in figure 3 for a hypothetical stream in the Blue Ridge-Piedmont hydrologic area. Steps 1-3 outlined for the preceding numerical examples are also required. The dashed lines in figure 3 indicate the procedure to follow: 
Assume a drainage area of $50 \mathrm{mi}^{2}$ and locate the value on figure 3 on the drainage area scale. For a 2-year flood, move upward to the curve representing the 2-year recurrence interval, then move horizontally to the discharge scale and read a value of about $2100 \mathrm{ft} 3 / \mathrm{s}$.

\section{MAGNITUDE AND FREQUENCY OF FLOODS IN URBAN BASINS}

This section of the report provides verification of methods for estimating the magnitude and frequency of floods along urban streams only in the Coastal Plain and Piedmont provinces of North Carolina. Applicability of the nationwide relations (Sauer and others, 1983) to the Coastal Plain and Piedmont is of principal interest.

\section{Coastal Plain}

Applicability of the nationwide urban flood relations for estimating flood discharges in the Coastal Plain was determined by comparing synthesized flood flows for five urban basins with corresponding nationwide relation estimates. Synthesized flood flows were obtained from a calibrated rainfal1-runoff model with historical rainfall data for input.

Five selected basins and some of their characteristics are listed in table 4, and their locations are shown in figure 6. Drainage areas range in size from 1.98 to $9.10 \mathrm{mi}^{2}$, and impervious cover varies from 2 to 30 percent. The systematic collection of flood discharge and concurrent rainfall data in these basins began in 1976. Although the length of record at each station varies from 3 to 4 years, from 25 to 35 flood peaks were recorded for each basin. The U.S. Geological Survey rainfall-runoff model developed by Dawdy and others (1972) and as reported by Carrigan (1973) was used to extend the peak discharge records for study sites to a longer, more representative time period.

The general structure of the model is explained in the following paragraph taken from Lichty and Liscum (1978, p. 4): 
The rainfall-runoff model used in this study is a simplified, conceptual, bulk-parameter, mathematical model of the surface-runoff component of flood-hydrograph response to storm rainfall (Dawdy, and others, 1972). The model deals with three components of the hydrologic cycle--antecedent soil moisture, storm infiltration, and surface-runoff routing. The first component simulates soil-moisture conditions at the onset of a storm period through the application of moisture-accounting techniques on a daily cycle. Estimates of daily rainfall, evaporation, and initial values of the moisture-storage variables are elements used in this component. The second component involves an infiltration equation ... and certain assumptions by which rainfall excess is determined on a 5-minute accounting cycle from stormperiod rainfall. Storm rainfall may be defined at 5-, 10-, 15-, 30-, or 60-minute intervals, but loss rates and rainfall excess amounts are computed at 5-minute intervals. The third component transforms the simulated time pattern of rainfall excess into a flood hydrograph by translation and linear storage attenuation (Clark, 1945)... For a more complete description of the model, see Dawdy and others (1972).

Table 4.--Some basin and climatic characteristics for selected urban basins in the Coastal Plain province

[ Units: $\mathrm{mi}^{2}$, square miles; in., inch; ft/mi, feet per mile]

\begin{tabular}{|c|c|c|c|c|c|c|c|}
\hline $\begin{array}{l}\text { Map index } \\
\text { number } \\
(f i g .6)\end{array}$ & Station name & $\begin{array}{l}\text { Basin } \\
\text { develop- } \\
\text { ment } \\
\text { factor }\end{array}$ & $\begin{array}{l}\text { Drainage } \\
\text { area } \\
\left(m i^{2}\right)\end{array}$ & $\begin{array}{l}\text { Rainfall } \\
\text { intensity } \\
\text { (in.) }\end{array}$ & $\begin{array}{l}\text { Slope } \\
(\mathrm{ft} / \mathrm{mi})\end{array}$ & $\begin{array}{l}\text { Storage } \\
\text { (percent) }\end{array}$ & $\begin{array}{c}\text { Impervious } \\
\text { area } \\
\text { (percent) }\end{array}$ \\
\hline 1 & $\begin{array}{c}\text { Greenmill Run at Arlington } \\
\text { Boulevard at Greenville }\end{array}$ & 2 & 9.10 & 2.3 & 9.3 & 0 & 2 \\
\hline 2 & $\begin{array}{l}\text { Big Ditch at Retha Street } \\
\text { at Goldsboro }\end{array}$ & 4 & 2.17 & 2.3 & 11 & 0 & 30 \\
\hline 3 & $\begin{array}{l}\text { Hominy Swamp at Phillips } \\
\text { Street at wilson }\end{array}$ & 5 & 7.92 & 2.1 & 11.4 & 0 & 11 \\
\hline 4 & $\begin{array}{l}\text { Hewletts Creek at Secondary } \\
\text { Road } 1102 \text { near wilmington }\end{array}$ & 3 & 1.98 & 2.6 & 15 & 0 & 6 \\
\hline 5 & Buckhead Creek near Owens & 3 & 2.76 & 2.2 & 15 & 0 & 8 \\
\hline
\end{tabular}




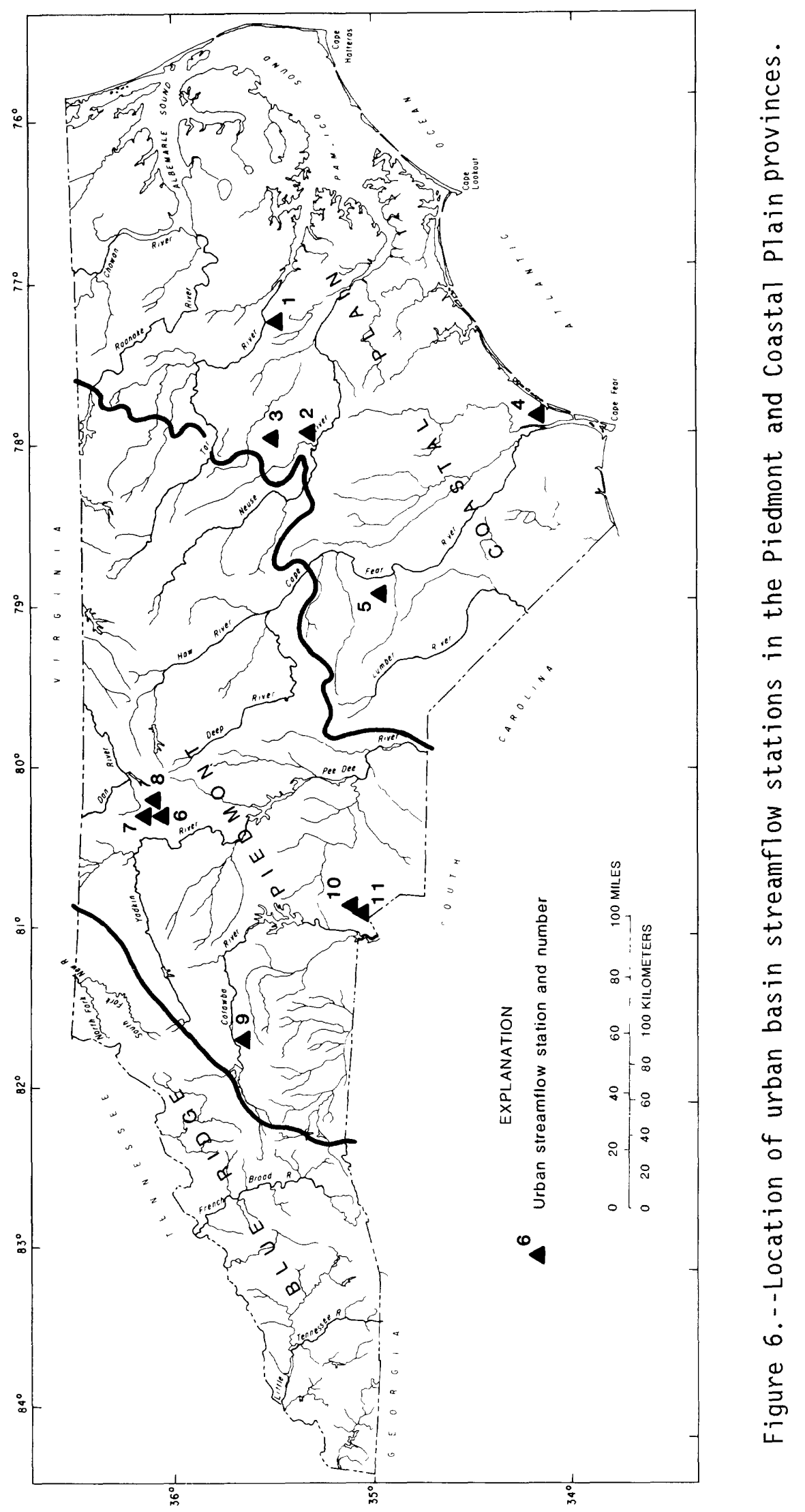


The model was calibrated using the observed flood and concurrent rainfall records of selected storm events. The model parameters were optimized to simulate streamflow hydrographs that:

1. minimized the root mean squared error (RMS) of observed versus simulated peaks,

2. neither systematically overestimated nor underestimated the observed peaks (slope of observed peaks versus simulated peaks approached one),

3. minimized the RMS of the observed time of peaks versus the simulated peaks, and

4. minimized the RMS of observed versus simulated discharge volume.

Table 5 summarizes statistics which describe the calibration.

Table 5.--Model calibration statistics for Coastal Plain urban basins [ RMS, root mean square]

\begin{tabular}{|c|c|c|c|c|c|c|c|}
\hline $\begin{array}{l}\text { Map index } \\
\text { number } \\
\text { (fig. } 6 \text { ) }\end{array}$ & $\begin{array}{l}\text { Slope of } \\
\text { regression of } \\
\text { observed versus } \\
\text { simulated peaks }\end{array}$ & $\begin{array}{l}\text { Correlation of } \\
\text { coefficient of } \\
\text { observed versus } \\
\text { simulated peaks }\end{array}$ & $\begin{array}{l}\text { RMS of } \\
\text { versus } \\
\text { peaks }\end{array}$ & $\begin{array}{l}\text { observed } \\
\text { simulated } \\
\text { (percent) }\end{array}$ & $\begin{array}{l}\text { RMS of observed } \\
\text { versus simulated } \\
\text { time to peak } \\
\text { (percent) }\end{array}$ & $\begin{array}{l}\text { RMS of } \\
\text { versus } \\
\text { volume }\end{array}$ & $\begin{array}{ll}\text { f } & \text { observed } \\
5 & \text { discharge } \\
\text { e (percent) }\end{array}$ \\
\hline 1 & 1.14 & 0.83 & & 34.5 & 24.5 & & 45.2 \\
\hline 2 & 1.01 & .91 & & 15.7 & 21.3 & & 29.2 \\
\hline 3 & .86 & .90 & & 22.7 & 29.8 & & 41.2 \\
\hline 4 & .92 & .98 & & 15.5 & 27.5 & & 34.8 \\
\hline 5 & .83 & .74 & & 30.6 & 22.4 & & 23.6 \\
\hline
\end{tabular}

After calibration of the model, long-term flood records of annual maximum discharge were synthesized using rainfall data from the highest three rainfall-storm events of each year from 1950 to 1980 collected at Wilson, North Carolina, where long-term data were available. The largest synthesized flood peak of each year was used to determine the floodfrequency distribution for each site by applying the log-Pearson type III method as described by the U.S. Water Resources Council (1981). The 10- and 100-year floods were compared to estimates from regional relations by Sauer and others (1983). 
Sauer and others (1983) developed nationwide relations for estimating peak discharge for urban streams. Application of these relations requires an estimate of the peak discharge for the basin in rural or undeveloped conditions. The nationwide relations adjust this estimate from a rural to an urban condition. The primary adjustment factor, or index of urbanization, is the basin development factor, BDF, a measure of the extent of development of the drainage system in the basin. The BDF includes evaluations of storm drains, channel improvements, and curb and gutter streets. A later study by Sauer (1985) showed that these nationwide relations are similar to regional relations developed throughout the southeastern United States, using drainage-area size and an index of urbanization as primary estimating parameters. The standard error of prediction for the nationwide relations is generally less than 40 percent, and according to Sauer (1985), the seven-parameter nationwide relations are applicable throughout the southeastern United States.

The seven-parameter nationwide relations are as follows:

$$
\begin{aligned}
& \mathrm{UQ}_{2}=2.35 \mathrm{~A}^{0.41} \mathrm{SL}^{0.17}\left(\mathrm{RI}_{2}+3\right)^{2.04}(\mathrm{ST}+8)^{-0.65}(13-\mathrm{BDF})^{-0.32} \mathrm{IA}^{0.15} \mathrm{RQ}_{2}{ }^{0.47} \\
& \mathrm{UQ}_{5}=2.70 \mathrm{~A}^{0.35} \mathrm{SL}^{0.16}\left(\mathrm{RI}_{2}+3\right)^{1.86}(\mathrm{ST}+8)^{-0.59}(13-\mathrm{BDF})^{-0.31} \mathrm{IA}^{0.11} \mathrm{RQ}_{5}{ }^{0.54} \\
& \mathrm{UQ}_{10}=2.99 \mathrm{~A}^{0.32} \mathrm{SL}^{0.15}\left(\mathrm{RI}_{2}+3\right)^{1.75}(\mathrm{ST}+8)^{-0.57}(13-\mathrm{BDF})^{-0.30} \mathrm{IA}^{0.09} \mathrm{RQ}_{10} 0.58 \\
& \mathrm{UQ}_{25}=2.78 \mathrm{~A}^{0.31} \mathrm{SL}^{0.15}\left(\mathrm{RI}_{2}+3\right)^{1.76}(\mathrm{ST}+8)^{-0.55}(13-\mathrm{BDF})^{-0.29} \mathrm{IA}^{0.07} \mathrm{RQ}_{25} 0.60 \\
& \mathrm{UQ}_{50}=2.67 \mathrm{~A}^{0.29} \mathrm{SL}^{0.15}\left(\mathrm{RI}_{2}+3\right)^{1.74}(\mathrm{ST}+8)^{-0.53}(13-\mathrm{BDF})^{-0.28} \mathrm{IA}^{0.06} \mathrm{RQ}_{50} 0.62 \\
& \mathrm{UQ}_{100}=2.50 \mathrm{~A}^{0.29} \mathrm{SL}^{0.15}\left(\mathrm{RI}_{2}+3\right)^{1.76}(\mathrm{ST}+8)^{-0.52}(13-\mathrm{BDF})^{-0.28} \mathrm{IA}^{0.06}{ }_{\mathrm{RQ}}{ }_{100} 0.63
\end{aligned}
$$

Where:

$U Q_{T}=$ Peak discharge, in cubic feet per second, for the urban watershed for a given recurrence interval $\mathrm{T}$. That is, $\mathrm{UQ}_{2}$ is the 2-year urban peak discharge; $U Q_{5}$ the 5 -year urban peak discharge, and so forth.

$A=$ Contributing drainage area, in square miles. In urban areas, drainage systems sometimes cross topographic divides. Such drainage changes should be accounted for when computing $A$. 
$S L=$ Main channel slope, in feet per mile, measured between points which are 10 percent and 85 percent of the main channel length up-stream from the study site. For sites where $\mathrm{SL}$ is greater than $70 \mathrm{ft} / \mathrm{mi}, 70 \mathrm{ft} / \mathrm{mi}$ is used in the equations.

$\mathrm{RI}_{2}=$ Rainfal1 intensity, in inches, for the 2-hour, 2-year occurrence determined from the U.S. Weather Bureau (1961).

ST = Basin storage, in percent: the percentage of the drainage basin occupied by lakes, reservoirs, swamps, and wetlands. In-channel storage of a temporary nature, resulting from detention ponds or roadway embankments, is not included in the computation of ST.

$B D F=$ Basin development factor, and index of the prevalence of the drainage aspects of (a) stormsewers, (b) channel improvements, (c) impervious channel linings, and (d) curb-and-gutter streets. The range of $B D F$ is $0-12$. A value of zero for BDF indicates the above drainage aspects are not prevalent but does not necessarily mean the basin is nonurban. A value of 12 indicates full development of the drainage aspects throughout the basin.

$I A=$ Impervious area, in percent: percentage of the drainage basin occupied by impervious surfaces, such as houses, buildings, streets, and parking lots.

$\mathrm{RQ}_{\mathrm{T}}=$ Peak discharge, in cubic feet per second, for an equivalent rural drainage basin in the same hydrologic area as the urban basin, and for a given recurrence interval $T$.

The simulated 10- and 100-year peak discharge for the selected Coastal Plain urban basins were compared to estimates from the nationwide relations. The comparison is summarized in table 6 . Generally, the nationwide estimates compare favorably to the simulated estimates in all the basins except for Hominy Swamp (site 3) where the simulated peak discharge for the 100-year recurrence interval differs greatly from the nationwide estimate. The difference is attributed to temporary storage behind numerous road crossings, culverts, and bridges which significantly reduce the peak discharge. Hominy Swamp was not considered for further analysis because the nationwide relations do not account for temporary storage. 
Table 6.--Summary of 10- and 100-year peak discharges in urban basins from simulated data and nationwide relations for the Coasta1 P1ain province

[ Units: $f t^{3} / s$, cubic feet per second]

\begin{tabular}{|c|c|c|c|c|c|}
\hline \multirow[b]{2}{*}{ Map } & \multirow[b]{2}{*}{$\begin{array}{l}\text { number } \\
6)\end{array}$} & \multicolumn{2}{|c|}{10 -year flood } & \multicolumn{2}{|c|}{ 100-year flood } \\
\hline & & $\begin{array}{c}\text { Simulated } \\
\left(\mathrm{ft}^{3} / \mathrm{s}\right)\end{array}$ & $\begin{array}{c}\text { Nat ionwide } \\
\left(f t^{3} / s\right)\end{array}$ & $\begin{array}{l}\text { Simulated } \\
\left(\mathrm{ft}^{3} / \mathrm{s}\right)\end{array}$ & $\begin{array}{c}\text { Nationwide } \\
\left(\mathrm{ft}^{3} / \mathrm{s}\right)\end{array}$ \\
\hline & 1 & 700 & 1.090 & 1.470 & 2,510 \\
\hline & 2 & 910 & 620 & 1,570 & 1.380 \\
\hline & 3 & 700 & 560 & 1,270 & 3,400 \\
\hline & 4 & 730 & 560 & 1930 & 1.340 \\
\hline & 5 & 220 & 310 & 370 & 600 \\
\hline
\end{tabular}

Independent linear regression analyses of the 10- and 100-year peak discharges for the remaining urban basins were conducted to determine if the nationwide equations were applicable in the Coastal Plain. The regression analyses resulted in estimates of slopes and intercepts of lines which related the simulated peak discharges to the peak discharges from the nationwide relations. If the nationwide equations are applicable, the intercepts of the regression lines must not differ significantly from zero and the slopes must not differ significantly from one. These parameters were tested using the Student's t-test which indicated that the intercepts were not significantly different from zero and that the slopes were not significantly different from one at the 5 and 1 percent levels for the 10 and 100-year peak discharge relations.

To estimate the precision of the nationwide relations in the coastal Plain, the discharges shown in table 6, excluding Hominy Swamp, were converted to logarithms and the differences between the logarithms of flood discharges for the simulated and nationwide relations were computed. The average difference $(\bar{x})$ and standard deviation of the difference $(S)$ were also determined. The root mean squared error (RMS), computed as:

$$
R M S=\sqrt{\bar{x}^{2}+S^{2}}
$$

is a measure of the precision of the nationwide relations as applied to the 
Coastal Plain study sites. RMS is considered an approximation of the standard error of estimate in such cases and compares favorably with the standard errors of prediction reported for the nationwide relations. The results are summarized in table 7 .

Table 7.--Average standard error of prediction of nationwide relations in the Coastal Plain province

\begin{tabular}{ccc}
\hline $\begin{array}{c}\text { Recurrence } \\
\text { interval } \\
\text { (years) }\end{array}$ & $\begin{array}{c}\text { Root mean squared error } \\
\text { (yoasta) Plain versus } \\
\text { nationwide (percent) }\end{array}$ & $\begin{array}{c}\text { Average standard error of } \\
\text { prediction nationwide 1' } \\
\text { (percent) }\end{array}$ \\
\hline 10 & 44 & 45 \\
100 & 49 & 53 \\
\hline
\end{tabular}

1/ From Saver and others (1983)

Although this analysis was based on only a very small sample (four sites), the stations used are from major urban areas widely distributed across the Coastal Plain and represent varied runoff conditions. The results of the analysis indicate that the nationwide relations are not biased for urban areas of the Coastal Plain and that the precision of the resulting estimates of peak discharge is as good as that expected from application of the nationwide relations to those areas for which the relations were verified. Therefore, the nationwide relations are deemed applicable to the Coastal Plain of North Carolina.

\section{Piedmont}

Applicability of the nationwide relations in the Piedmont was also tested. Six selected urban basins and their characteristics are listed in table 8 and are located in figure 6 . The data set consisted of the 25 - and 100-year peak discharges determined by Putnam (1972) using long-term, simulated data at these urban Piedmont sites (table 9), along with the corresponding nationwide relation estimates. The 25 - and 100 -year recurrence intervals were used instead of the 10- and 100-year intervals because Putnam (1972) did not publish smaller than 25-year recurrence intervals for the simulated data. Where basin slopes exceeded 70 feet per 


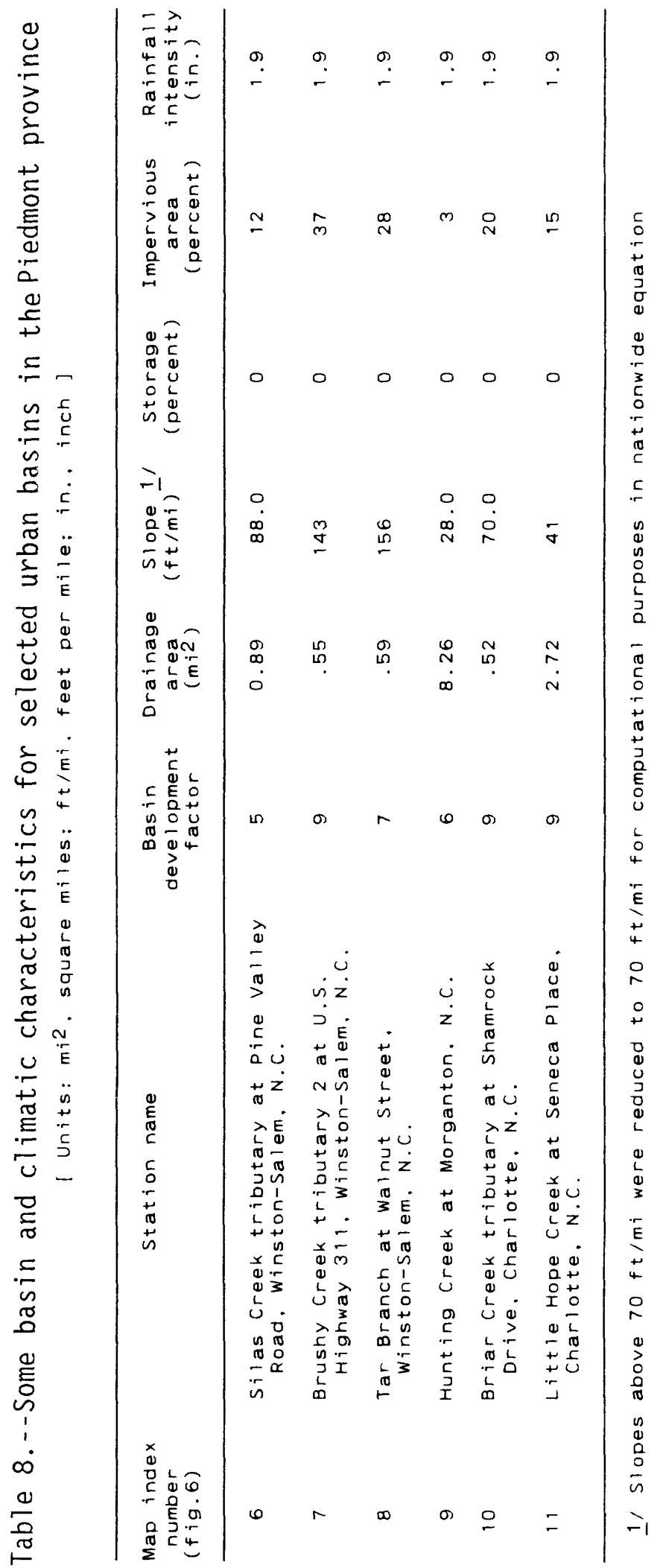


mile, the slope was set at 70 feet per mile for calculations, which is consistant with the usage recommended by Sauer and others (1983).

Table 9.--Summary of 25- and 100-year peak discharges in urban basins from simulated data and nationwide flood relations for the Piedmont province

[ Units: $\mathrm{ft}^{3} / \mathrm{sec}$. cubic feet per second]

\begin{tabular}{|c|c|c|c|c|}
\hline \multirow[b]{2}{*}{$\begin{array}{l}\text { Map index } \\
\text { number } \\
(f i g .6)\end{array}$} & \multicolumn{2}{|c|}{25 -year flood } & \multicolumn{2}{|c|}{ 100-year flood } \\
\hline & $\underset{\substack{\text { Simulated } \\
\left(\mathrm{ft}^{3} / \mathrm{s}\right)}}{1 /}$ & $\begin{array}{l}\text { Nationwide } \\
\left(\mathrm{ft}^{3} / \mathrm{s}\right)\end{array}$ & $\begin{array}{c}\text { Simulated } \\
\left(\mathrm{ft}^{3} / \mathrm{s}\right)\end{array}$ & $\begin{array}{l}\text { Nat ionwide } \\
\left(\mathrm{ft}^{3} / \mathrm{s}\right)\end{array}$ \\
\hline 6 & 1.020 & 660 & 1,200 & 990 \\
\hline 7 & 1,250 & 620 & 1,450 & 920 \\
\hline 8 & 1,450 & 570 & 1.700 & 850 \\
\hline 9 & 2,200 & 2,580 & 3,000 & 3,860 \\
\hline 10 & 600 & 570 & 700 & 850 \\
\hline 11 & 1,950 & 1.650 & 2,200 & 2,440 \\
\hline
\end{tabular}

1/ From Putnam (1972)

One parameter, the basin development factor (BDF), was determined from field inspections of the basins under current conditions to reflect the increased development which has occurred since Putnam's study in 1972. Because the BDF's based upon increased development should result in higher peak discharge estimates from the nationwide relations, the comparison between Putnam's (1972) peak discharge estimates and the nationwide estimates can be expected to be biased to some extent.

A statistical test, similar to that described for the Coastal Plain data, was conducted. Separate linear regression analyses of simulated versus nationwide estimates of peak discharges were conducted for the 25and 100-year recurrence intervals. The intercepts of the 1 inear regressions of the simulated data versus the nationwide estimates did not differ significantly from zero, nor did the slopes differ significantly from one, suggesting that the nationwide relations produced unbiased estimates of peak discharges in the Piedmont of North Carolina. 
The root mean squared errors (RMS) were also calculated and compared to the standard errors of estimate reported by Putnam (1972) and shown in table 10. The RMS for the 25-year recurrence interval is somewhat high (64 percent) for that relation to be considered a reasonable estimator of peak discharges in the Piedmont of North Carolina. Caution is urged in the interpretation of this statistic, however, because one nationwide equation parameter, the BDF, was determined for the basins under present conditions and may not reflect basin conditions present when Putnam modeled the streams. In this case, the large RMS may be due solely to the incompatibility of the larger BDF with the other data and does not necessarily indicate an inherent bias in the nationwide equation with respect to its use in determining estimates of peak discharges in the Piedmont. Therefore, the applicability of the nationwide relations cannot be rejected on the basis of this one statistic. The analysis is inconclusive; the relations do not appear biased, but no recommendation as to whether or not the nationwide relations are applicable to the Piedmont of North Carolina can be determined from the data presently available.

Table 10.--Average standard error of prediction of nationwide relations in the Piedmont province

\begin{tabular}{ccc}
\hline $\begin{array}{l}\text { Recurrence } \\
\text { interva) } \\
\text { (years) }\end{array}$ & $\begin{array}{c}\text { Root mean squared error of } \\
\text { Piedmont versus nationwide } \\
\text { (percent) }\end{array}$ & $\begin{array}{c}\text { Average standarderror } \\
\text { of prediction Piedmont } \\
\text { relation (percent) }\end{array}$ \\
\hline 25 & 64 & 46 \\
100 & 42 & -- \\
\hline 1/ From Putnam (1972)
\end{tabular}

\section{SUMMARY}

In the first section of this report, regional flood-frequency relations were developed for rural streams in North Carolina. Flood data from sites with 10 or more years of record through September 1984 and basincharacteristics data were used in a multiple linear-regression analys is to develop the relations. 
Guidelines and procedures recommended by the U.S. Water Resources Council (1981) were used in the flood-frequency analysis. The Pearson Type III distribution with log transformation of the annual maximum discharges was used as the basic distribution. Multiple regressions were first run on a statewide basis by using flood discharges and basin characteristics; plots of residual errors showed regional patterns in three hydrologic areas:

Blue Ridge-Piedmont, (2) Coastal Plain, and (3) Sand Hills. Regional flood relations were developed for each of these areas.

Regional relations showed peak discharges as a function of drainage area. The inclusion of other basin and climatic characteristics in the relations reduced the average standard error of estimate only about 2 percent for all hydrologic areas. Average standard error of estimate of the regional relations was 24 percent for the Sand Hill hydrologic area, 39 percent for the Coastal Plain hydrologic area, and 44 percent for the Blue Ridge-Piedmont hydrologic area. Accuracy of the estimates in terms of equivalent years of record is provided. Methods were described to adjust peak discharge estimates at gaged and ungaged sites based on the weighting of regional and station estimates. Rural flood relations provided in this report are applicable to streams that are not significantly affected by tide or by development effects such as regulation or urbanization.

In the second section of this report, test of the applicability of nationwide relations by Sauer and others (1983) to Coastal Plain and Piedmont areas in North Carolina were described. Rainfall-runoff data for basins in the Coastal Plain, ranging in size from 1.98 to $9.10 \mathrm{mi}^{2}$ and in impervious area from 2 to 30 percent, were used to calibrate rainfall-runoff models for each basin. Long-term rainfall data (1950-80) for the National Weather Service station in Wilson, North Carolina, were used to synthesize annual peak discharges for each basin. Synthesized peak discharges were used in developing a flood-frequency distribution for each site.

The flood-frequency distribution was compared to the nationwide relations (Sauer and others, 1983). The standard error of estimate was 44 percent for the 10-year flood and 49 percent for the 100-year flood. 
Although the data base used in this comparison was limited, the nationwide relations are deemed applicable to urban areas of the Coastal Plain within reasonable limits of accuracy.

The nationwide relations were also compared with observed data from six sites from Putnam (1972) in the Piedmont. The standard error of estimate for the comparison was 64 and 42 percent for the 25- and 100-year floods, respectively. No recommendation as to the applicablility of the nationwide relations can be determined from the data presently available. 


\section{SELECTED REFERENCES}

Carney, C.B., 1960, Climates of the states--North Carolina: U.S. Weather Bureau, Climatography of the United States no. 60-31, $20 \mathrm{p}$.

Carrigan, P.H., Jr., 1973, Calibration of U. S. Geological Survey rainfal1runoff model for peak flow synthesis--natural basins: U.S. Geological Survey Open-File Report, Reston, Virginia, $109 \mathrm{p}$.

Clark, C.0., 1945, Storage and the unit hydrograph: American Society of Civil Engineers Transactions, v. 110, p. 1419-1488.

Dalrymple, T., 1960, Flood-frequency analysis: U.S. Geological Survey Water-Supply Paper 1543-A, $80 \mathrm{p}$.

Daniels, R.B., Kleiss, H.J., Buol, S.W., Byrd, H.J., and Phillips, J.A., 1984, Soil systems in North Carolina: North Carolina State University, North Carolina Agricultural Research Service, Bulletin 467, p. 14.

Dawdy, D.R., Lichty, R.W., and Bergmann, J.M., 1972, A rainfall-runoff simulation model for estimation of flood peaks for small drainage basins: U.S. Geological Survey Professional Paper 506-B, 28 p.

Eder, B.K., Davis, J.M., and Robinson, P.J., 1983, Variations in monthly precipitation over North Carolina: University of North Carolina, Water Resources Research Institute, Report no. 185, 50 p.

Fenneman, N.M., 1938, Physiography of eastern United States: New York, McGraw-Hill Book Company, Inc., $714 \mathrm{p}$.

Goddard, G.C., Jr., Jackson, N.M., Jr., Hubbard, E.F., and Hinson, H.G., 1970, A proposed streamflow data program for North Carolina: U.S. Geological Survey Open-File Report.

Hardison, C.H., 1971, Prediction error of regression estimates of streamflow characteristics at ungaged sites: U.S. Geological Survey Professional Paper 750-C, p. C228-C236. 
Hinson, H.G., 1965, Floods on small streams in North Carolina, Probable magnitude and frequency: U.S. Geological Survey Circular 517, 7 p.

Jackson, N.M., Jr., 1976, Magnitude and frequency of floods in North Carolina: U.S. Geological Survey Water-Resources Investigations Report 76-17.

Kirby, W., 1979, Log-Pearson Type III flood-frequency analysis using guidelines of Water Resources Council (Program J407): U.S. Geological Survey WATSTORE user's guide, v. 4 , chap. I-C.

Kopec, R.J., and Clay, J.W., 1975, Climate and air quality (chap. 5) in North Carolina atlas, Portrait of a changing southern state: The University of North Carolina Press, Chapel Hill, p. 92-111.

Langbein, W.B., and Iseri, K.T., 1960, General introduction and hydrologic definitions: U.S. Geological Survey Water-Supply Paper 1541-A, 29 p.

Lee, W.D., 1955, The soils of North Carolina, their formation, identification, and use: North Carolina Agricultural Experiment Station, Technical Bulletin no 115, p1. 1.

Lichty, R.W., and Liscum, Fred, 1978, A rainfall-runoff modeling procedure for improving estimates of T-year annual floods for small drainage basins: U.S. Geological Survey Water-Resources Investigations 78-7, $44 \mathrm{p}$.

Lutz, J.F., 1969, The movement and storage of water in North Carolina soils and the role of the soil in determining water quality: University of North Carolina, Water Resources Research Institute Report no. 24, 43 p.

Putnam, A.L., 1972, Effects of urban development on floods in the Piedmont province of North Carolina: U.S. Geological Survey Open-File Report.

Sauer, V.B., 1985, New studies of urban flood frequency in the southeastern U. S., paper presented at 1985 International Symposium on Urban Hydrology at Lexington, Kentucky. 
Sauer, V.B., Thomas, W.0., Jr., Stricker, V.A., and Wilson, K.V., 1983, Flood characteristics of urban watersheds in the United States-Techniques for estimating magnitude and frequency of urban floods: U.S. Geological Survey Water-Supply Paper 2207, 103 p.

Speer, P.R., and Gamble, C.R., 1964a, Magnitude and frequency of floods in the United States, Part 2-A, South Atlantic Slope basins, James River to Savannah River: U.S. Geological Survey Water-Supply Paper 1673, $329 \mathrm{p}$.

1964b, Magnitude and frequency of floods in the United States, Part 3-B, Cumberland and Tennessee River basins: U.S. Geological Survey Water-Supply Paper 1676, $339 \mathrm{p}$.

1965, Magnitude and frequency of floods in the United States, Part 3-A, Ohio River basin except Cumberland and Tennessee River basins: U.S. Geological Survey Water-Supply Paper 1675, $630 \mathrm{p}$.

Stuckey, J.L., 1965, North Carolina--its geology and mineral resources: North Carolina Department of Conservation and Development, North Carolina State University Print Shop, Raleigh, N.C., 550 p.

U.S. Water Resources Counci1, 1981, Guidelines for determining flood flow frequency: U.S. Water Resources Council Bulletin 17B, 183 p.

U.S. Weather Bureau, 1961, Rainfall frequency atlas of the United States: Technical Paper no. 40, p. 39. 


\section{GLOSSARY}

Some of the technical terms used in this report are defined here for convenience. See Dalrymple (1960) and Langbein and Iseri (1960) for additional information regarding flood-frequency analyses and associated hydrologic terminology. Statistical terms are defined with respect to flood analysis applications described in this report.

Annual peak discharge: The highest peak discharge in a water year, in cubic feet per second.

Basin characteristics: Parameters that describe the physical and climatic factors of a drainage basin. Parameters used in this study include drainage area, channel length and slope, storage, soil-infiltration index, mean annual precipitation, and rainfall intensity.

Basin development factor (BDF): An index of the prevalence of the drainage aspects of (a) storm sewers, (b) channel improvements, (c) impervious channel linings, and (d) curb-and-gutter streets. The range of BDF is 0-12. A value of zero for BDF indicates the above drainage aspects are not prevalent but does not necessarily mean the basin is nonurban. A value of 12 indicates full development of the drainage aspects throughout the basin.

Basin length (L): The length, in miles, measured on topographic maps along the main channel from the gaging station to the basin divide.

Bias: Systematic error or tendency to either over- or underestimate the true value.

Channel slope (SL): The main channel slope, in feet per mile, measured between points which are 10 percent and 85 percent of the main channel length upstream from the study site. For urban sites where $S L$ is greater than $70 \mathrm{ft} / \mathrm{mi}, 70 \mathrm{ft} / \mathrm{mi}$ is used in the equations.

Crest-stage gage: A device for recording the elevation of the flood crest or peak of a stream. 
Distribution: Function describing the relative frequency with which events of various magnitudes occur.

Drainage area (A): The drainage area of a stream, in square miles, at a specified location is that area, measured in a horizontal plane, which is enclosed by a drainage divide. In urban areas, drainage systems sometimes cross topographic divides. Such drainage changes should be accounted for when computing $A$.

Equivalent years of record: Number of years of stream-flow record that would be necessary to produce a flood-frequency estimate with accuracy equal to that of the regression analysis.

Exceedence probability: Probability that a random event will exceed a specified magnitude in a given time period, usually one year unless otherwise indicated. Recurrence interval is computed as the inverse of exceedence probability.

Flood: An overflow or inundation that comes from a river or other body of water and causes or threatens damage. Any relatively high streamflow overtopping the natural or artificial banks in any reach of a stream.

Generalized skew coefficient $(\bar{G})$ : A skew coefficient of logarithms of annual maximum discharges derived by a procedure which integrates values obtained at many locations.

Impervious area (IA): The percentage of the drainage basin occupied by impervious surfaces, such as houses, buildings, streets, and parking lots.

Lag time: Time, in hours, computed as the time from center-of-mass of rainfall excess to the center-of-mass of the corresponding runoff. Computed only for stations having continuous rainfall and runoff data.

Logarithmic mean (M): The mean of logarithms of annual maximum discharges for a gaging station. 
Mean $(\bar{x})$ : The value obtained by dividing the sum of a series of values by the number of values in the series.

Multiple correlation coefficient: A measure of the explanatory power of a regression involving three or more hydrologic variables.

Outlier: A nonrepresentative annual peak discharge event.

Rainfall intensity $\left(\mathrm{RI}_{2}\right)$ : Rainfall intensity, in inches, for the 2-hour, 2year occurrence. Determined from U.S. Weather Bureau (1961).

Recurrence interval (return period): The average interval of time within which the given flood will be exceeded at least once.

Residual: The difference between a station value and a value predicted by a regression equation.

Root mean squared (RMS): An approximation of the standard error of prediction resulting from application of a regression equation to an independent data set not used to develop the regression.

Rural maximum discharge $\left(R Q_{T}\right)$ : The maximum discharge, in cubic feet per second, for an equivalent rural drainage basin in the same hydrologic area as the urban basin and for recurrence interval $\mathrm{T}$. For this study equivalent rural discharges were computed from applicable Geological Survey regional flood-frequency reports, as indicated in table 1 .

Skew coefficient: Relative measure of the asymmetry of a flood-frequency distribution.

Soil infiltration index (SI): An index to soil infiltration capacity in inches per hour. The soil indices were determined from soil samples collected, analyzed, and reported by Lutz (1969), and generalized on the basis of a map showing soil types throughout the State, prepared by Lee (1955). 
Standard deviation (S): A measure of the amount of variation in a sample. The standard deviation is determined by taking the square root of the average squared deviations of the observations from the mean.

Standard error of estimate: A measure of the reliability of a regression equation. In this report, the standard error is given as an average percent value representing the average range about the regression equation that includes about 68 percent of al1 regression data points. More technically, the standard error is the standard deviation of the residuals about the regression equation.

Standard error of prediction: A measure of how well the regression equation will estimate the dependent variables at locations other than calibration sites.

Station skew coefficient $(G)$ : A numerical measure or index of the lack of symmetry in a distribution of the logarithms of the annual maximum discharges for a gaging station.

Streamflow station: A gaging station where a record of discharge of a stream is obtained. Within the Geological Survey, this term is used only for those gaging stations where a continuous record of discharge is obtained.

Stream length: Distance in miles measured on topographic maps along the main channel from the gaging station to the basin divide.

Student's " $t$ " test: A standard statistical test frequently used to determine the significance of a deviation of an individual parameter from a specified value.

Water year: The 12-month period beginning October 1 and ending September 30 and designated by the calender year in which it ends.

Weighted means: A value obtained by multiplying each of a series of values by its assigned weight and dividing the sum of those products by the sum of weights. 


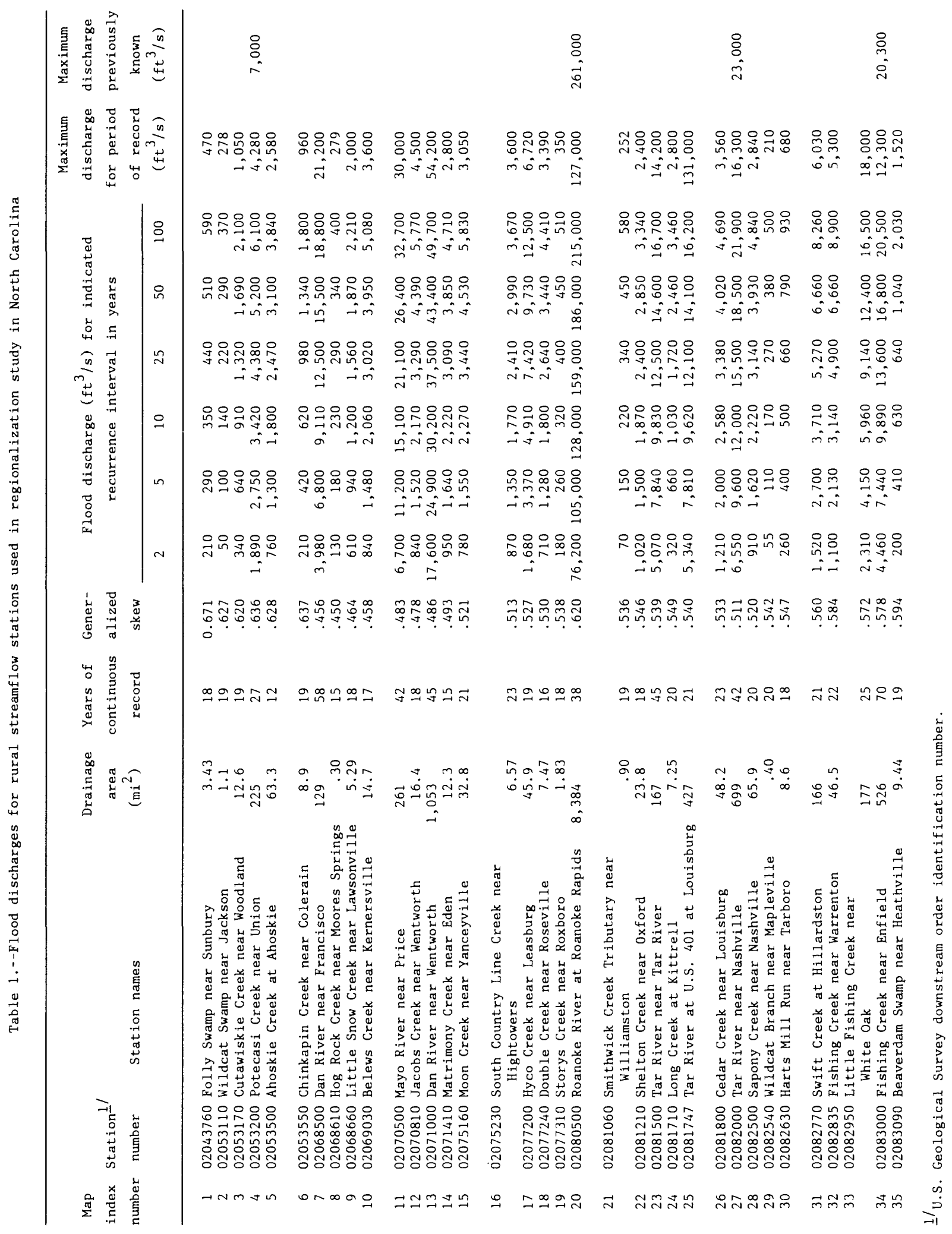




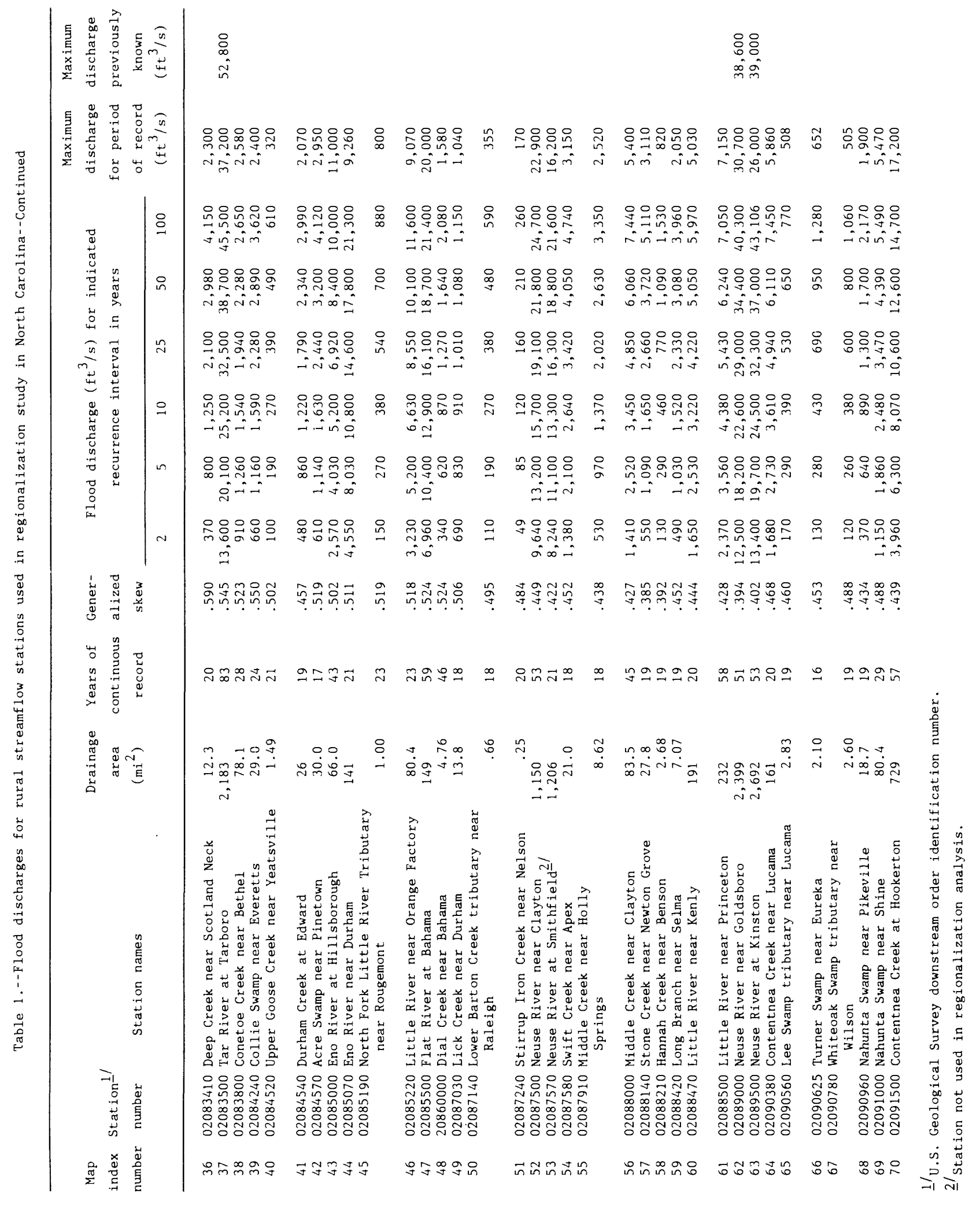




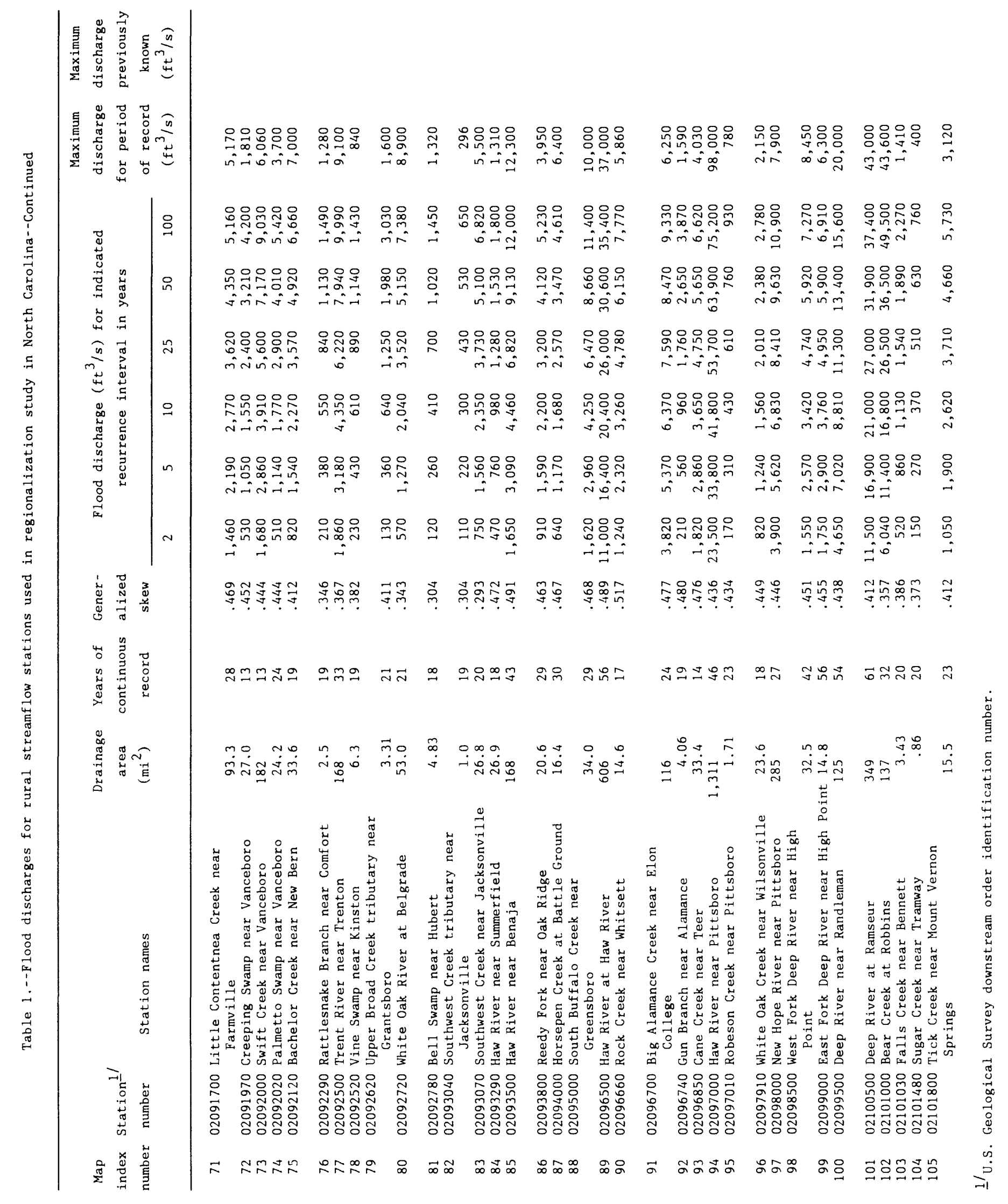




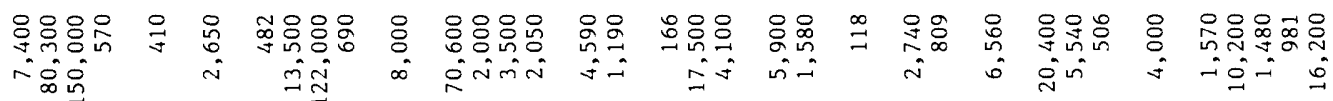

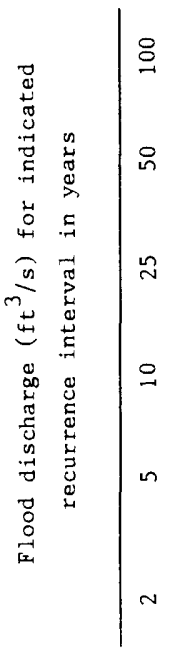

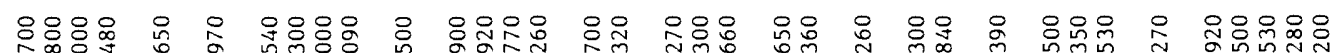
它主

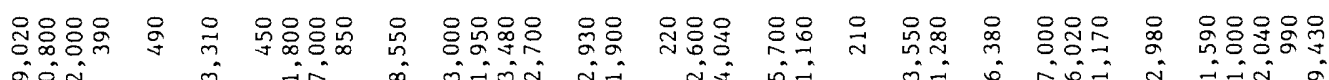

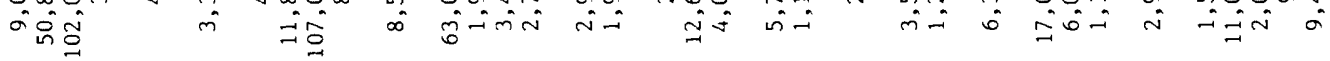

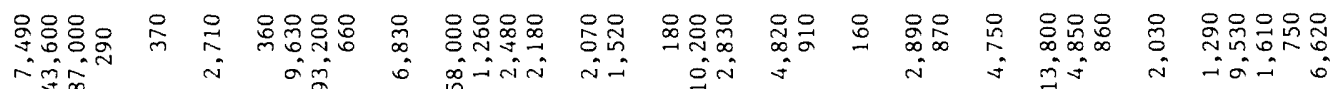

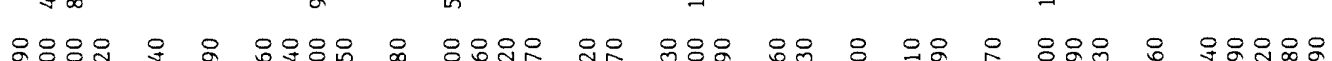

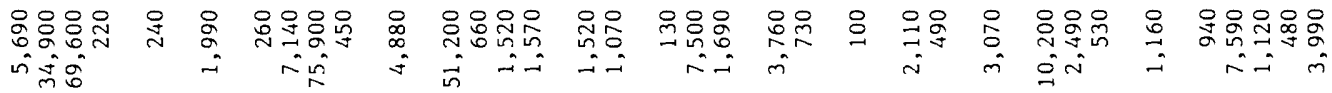

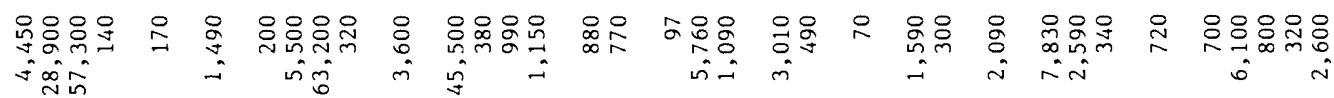

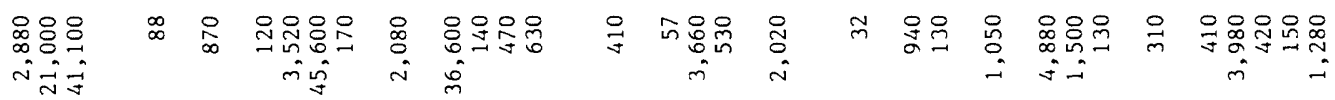

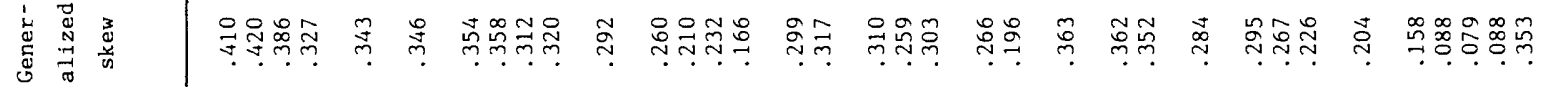

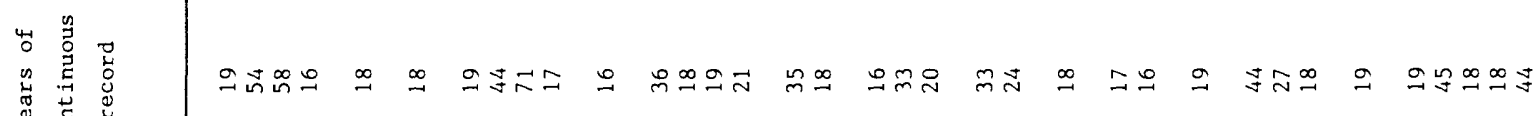

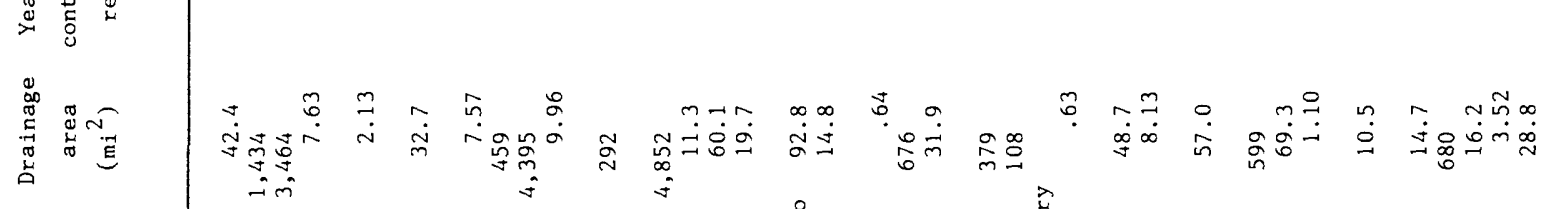

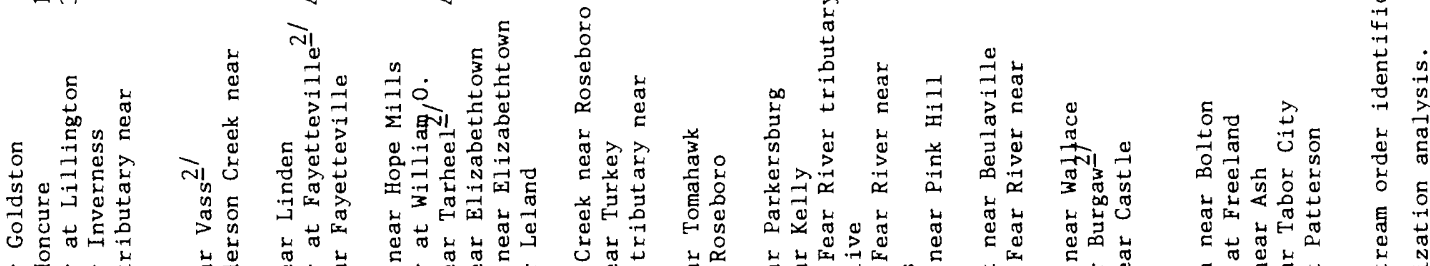

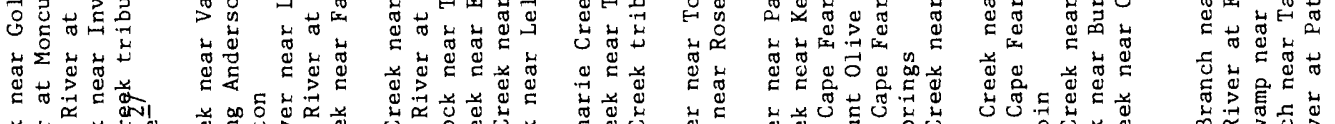

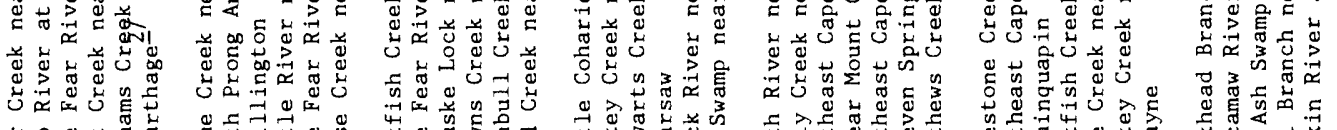

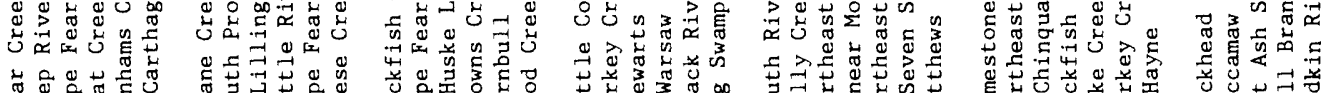

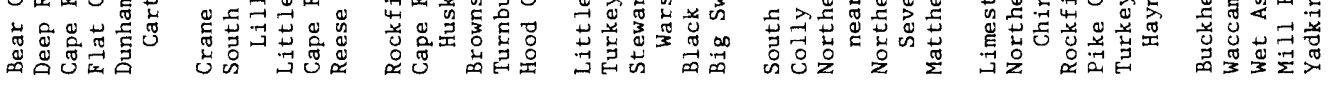

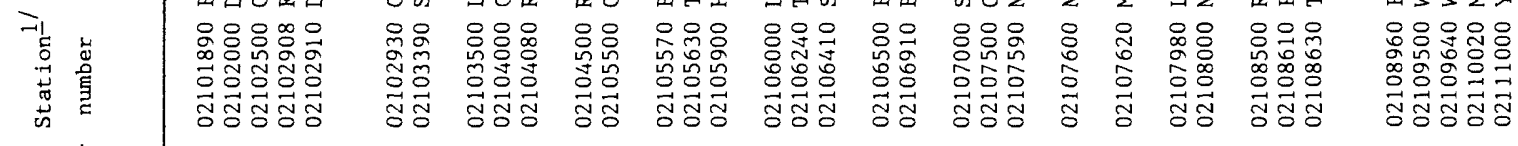

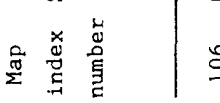




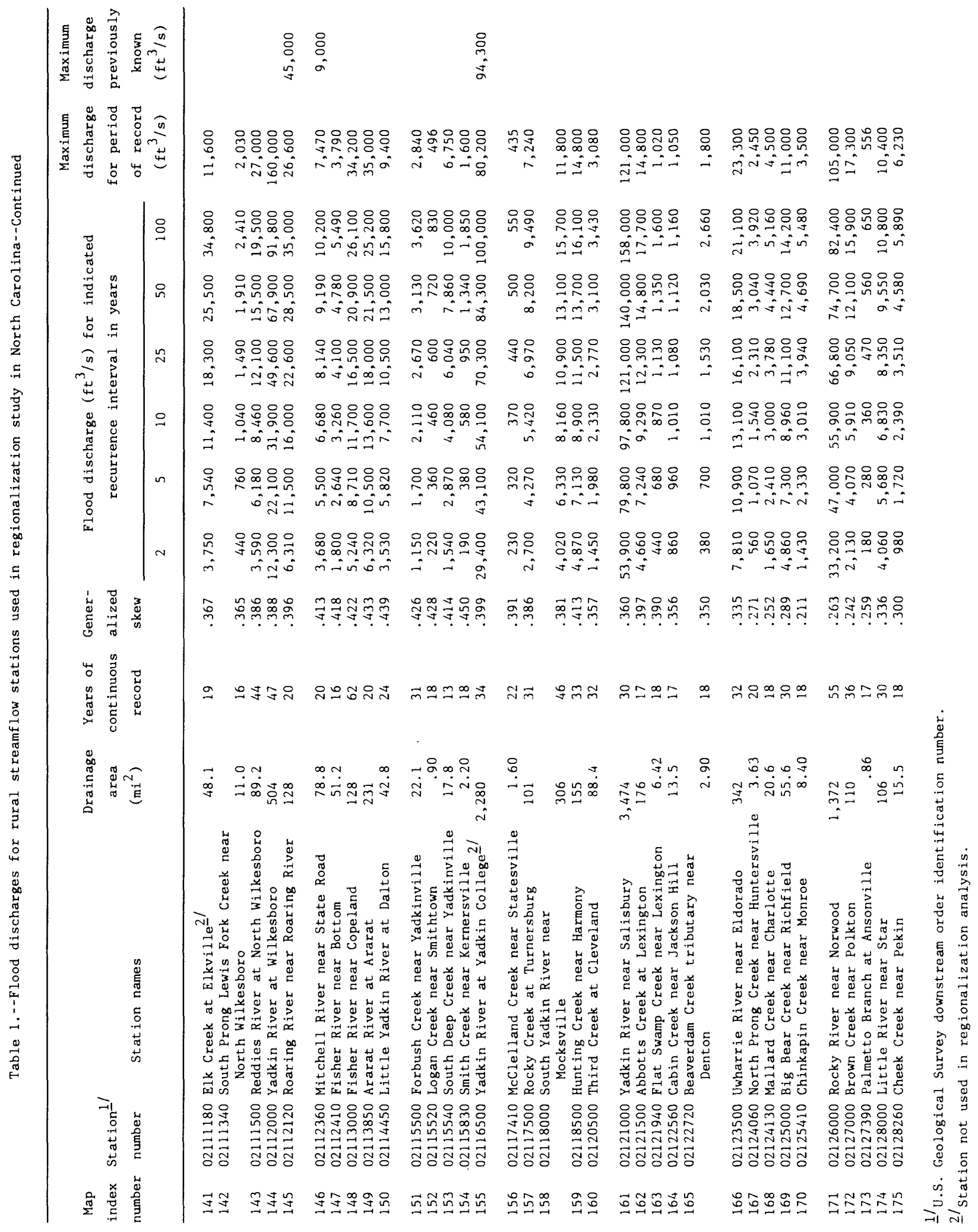




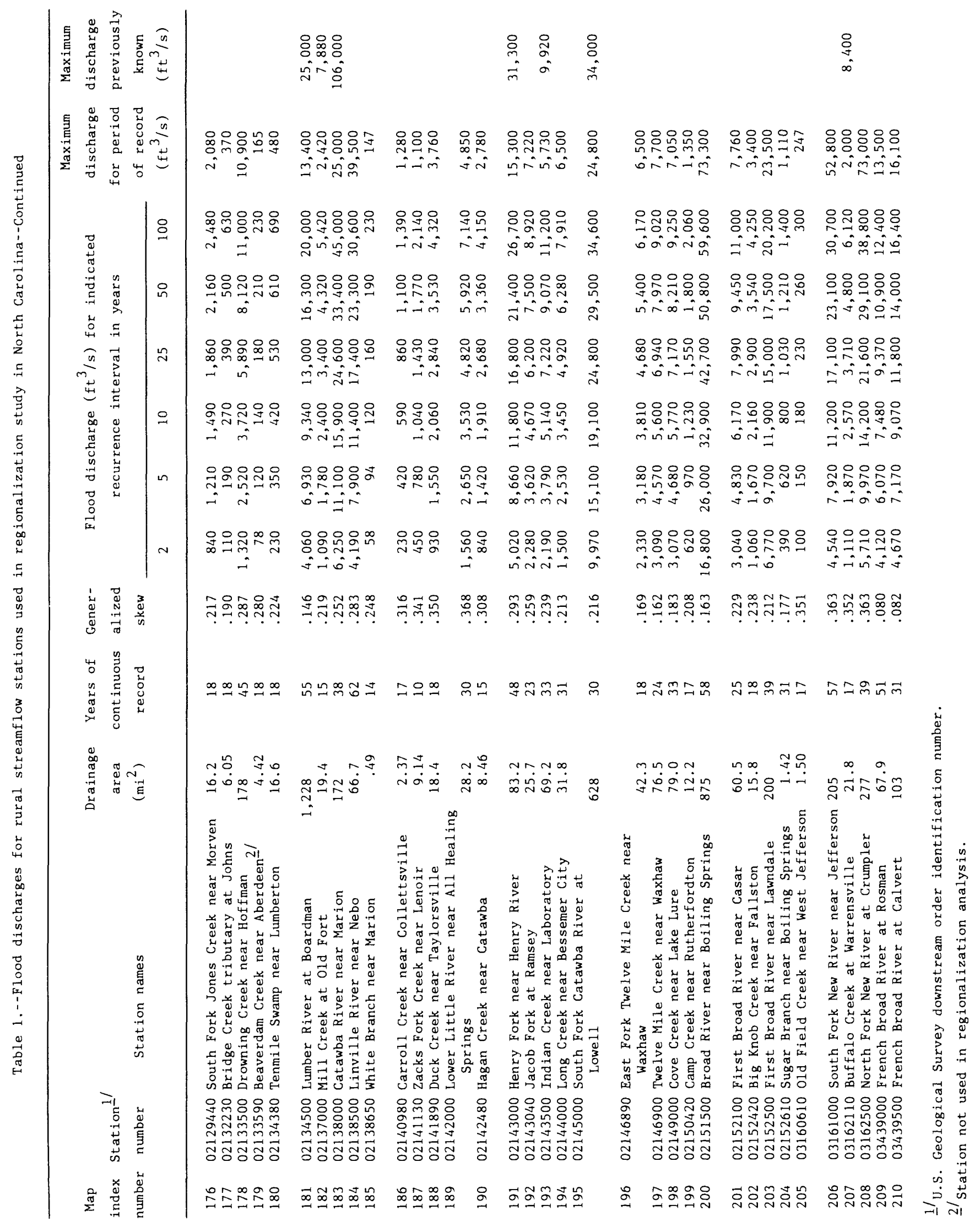









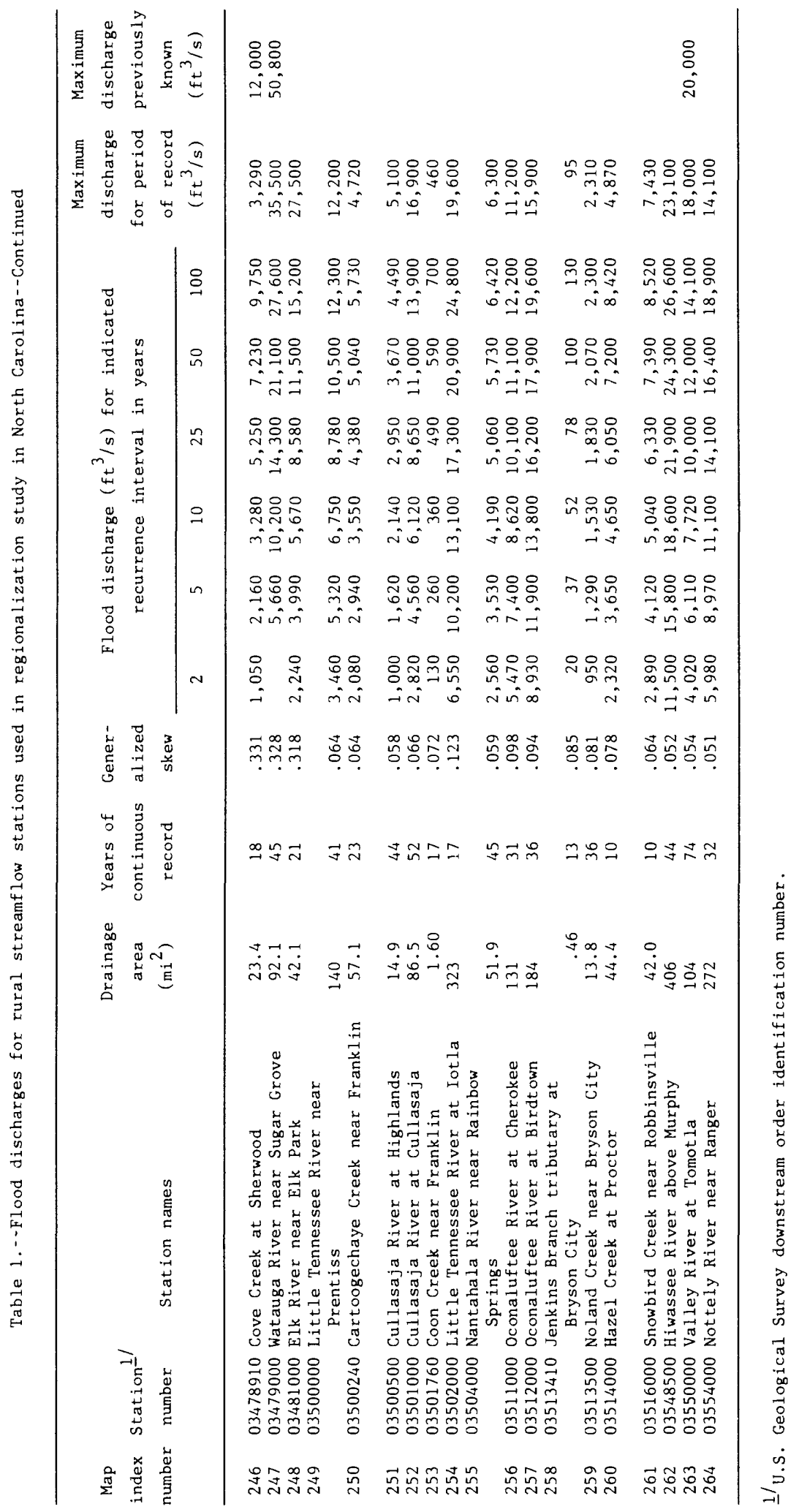

